\title{
Graphene-based 3D scaffolds in tissue engineering: fabrication, applications, and future scope in liver tissue engineering
}

This article was published in the following Dove Press journal: International Journal of Nanomedicine

\author{
Renu Geetha Bai ${ }^{1}$ \\ Kasturi Muthoosamy' \\ Sivakumar Manickam ' \\ Ali Hilal-Alnaqbi ${ }^{2}$
}

'Nanotechnology and Advanced Materials (NATAM), Faculty of Science and Engineering, University of

Nottingham Malaysia, Semenyih, Selangor, 43500, Malaysia; ${ }^{2}$ Electromechanical

Technology, Abu Dhabi Polytechnic, Abu

Dhabi, United Arab Emirates
Correspondence: Ali Hilal-Alnaqbi Electromechanical Technology, Abu Dhabi Polytechnic, P.O. Box II I499, Abu Dhabi, United Arab Emirates

Email Ali.Alnaqbi@adpoly.ac.ae

\begin{abstract}
Tissue engineering embraces the potential of recreating and replacing defective body parts by advancements in the medical field. Being a biocompatible nanomaterial with outstanding physical, chemical, optical, and biological properties, graphene-based materials were successfully employed in creating the perfect scaffold for a range of organs, starting from the skin through to the brain. Investigations on 2D and 3D tissue culture scaffolds incorporated with graphene or its derivatives have revealed the capability of this carbon material in mimicking in vivo environment. The porous morphology, great surface area, selective permeability of gases, excellent mechanical strength, good thermal and electrical conductivity, good optical properties, and biodegradability enable graphene materials to be the best component for scaffold engineering. Along with the apt microenvironment, this material was found to be efficient in differentiating stem cells into specific cell types. Furthermore, the scope of graphene nanomaterials in liver tissue engineering as a promising biomaterial is also discussed. This review critically looks into the unlimited potential of graphene-based nanomaterials in future tissue engineering and regenerative therapy.
\end{abstract}

Keywords: graphene, 3D, tissue engineering, scaffold, microenvironment, stem cells, liver, regenerative therapy

\section{Introduction}

\section{Tissue engineering}

The potential advancements experienced in the medical field through the introduction of tissue engineering involve the repair/recreation of structure and function of live tissue or organs. This practice comprises the utilization of various aspects of cell biology, materials chemistry, biomaterials engineering, immunology, preclinical, clinical investigations, etc. The huge growing demand for organ and tissue transplants stimulated continuous investigations on the rejuvenating properties of cells. This encouraged the development of a revolutionary technique called tissue engineering, as an ultimate solution toward the tissue and organ damage. The critical factors to be considered in the regeneration of cells involve; the nature and origin of cells, scaffold materials used, scaffold design, cellular and outer environment for tissue formation, etc. ${ }^{1-5}$

Introduction of stem cells to tissue engineering for tissue/organ repair revealed a novel perception of regenerative therapy. The undifferentiated pluripotent cells were utilized for the growth, proliferation, and differentiation to specific tissue/ organ leading to successful trials in preclinical and clinical investigations. During 
the early stages, tissue engineering was used in the preparation of tissue construct outside the body and was then incorporated into the living being. However, in the current scenario, clinical tissue engineering involves the successful implantation and evaluation of the prepared tissue/ organ via clinical studies. Numerous tissue engineeringbased therapies such as wound healing and orthopedic applications have obtained approval from Food and Drug Administration for clinical experiments and are commercially available. The future of tissue engineering depends on three-dimensional (3D) scaffolds created by novel promising biomaterials. ${ }^{6-8}$ This review gives a bird's eye view on recent advances in graphene-based 3D scaffolds in tissue engineering applications as illustrated in Figure 1.

\section{Scaffolds}

Scaffolds are essential components for the regeneration of tissues in 3D cell culture. From the mechanical aspect, scaffolds assist to withstand external pressures and give structural support to the tissue to be regenerated. Considering the biological aspect, scaffolds are structures which support the development of extracellular matrix (ECM) and cell establishment. Moreover, the permeability of scaffold is another factor, where scaffolds should allow the transfer of nutrients from culture media and support the removal of toxic metabolites/by-products from the tissues without hindering the culturing conditions. Timely degradation of the scaffold material by allowing the takeover of the cells is another critical feature to be considered to support the regenerative tissue. Limited cell-cell interaction, lack of cellular organization, and difference from the real in vivo scenario are the main limiting factors of two-dimensional (2D) cell culture which could be improved by the use of more advanced $3 \mathrm{D}$ cell culture. ${ }^{9-12}$

\section{D and 3D scaffolds}

Generally, the types of cell culture are explained in terms of the dimension of cell growth as a $2 \mathrm{D}$ or $3 \mathrm{D}$ cell cultures. Figure 2 shows the pictorial representation of a $2 \mathrm{D}$ and $3 \mathrm{D}$ cell culture. 2D indicates the growth of cells as a monolayer in culture flasks, which normally involves a single type of cells growing on a planar surface. 2D cultures are extensively used in cell research due to factors such as easier cellular observation, direct measurement feasibility, inexpensive nature, prime scope in drug testing, and cytocompatibility. However, 2D cultures are not a perfect representation of the normal cellular environment in an organism. As a result, the 2D cultures exhibit abnormal structural features, mechanical constraints and often caused misleading results when tested in vivo. Ultimately, when considering pro-apoptotic factors in drug discovery and biocompatibility analysis, a remarkable difference in the results was observed in 2D and 3D cell cultures. Major changes were observed in terms of cell polarity, cell

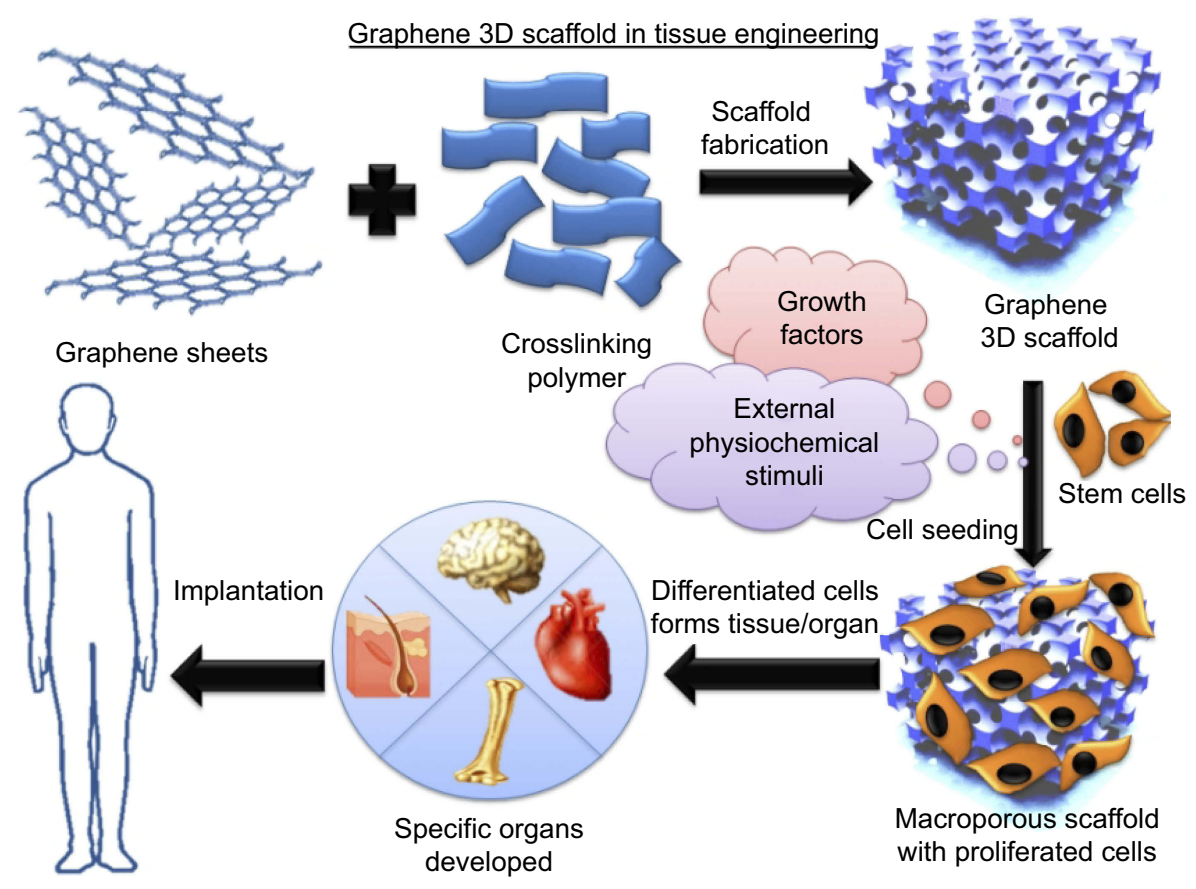

Figure I Schematic diagram of graphene 3D scaffolds in tissue engineering. 


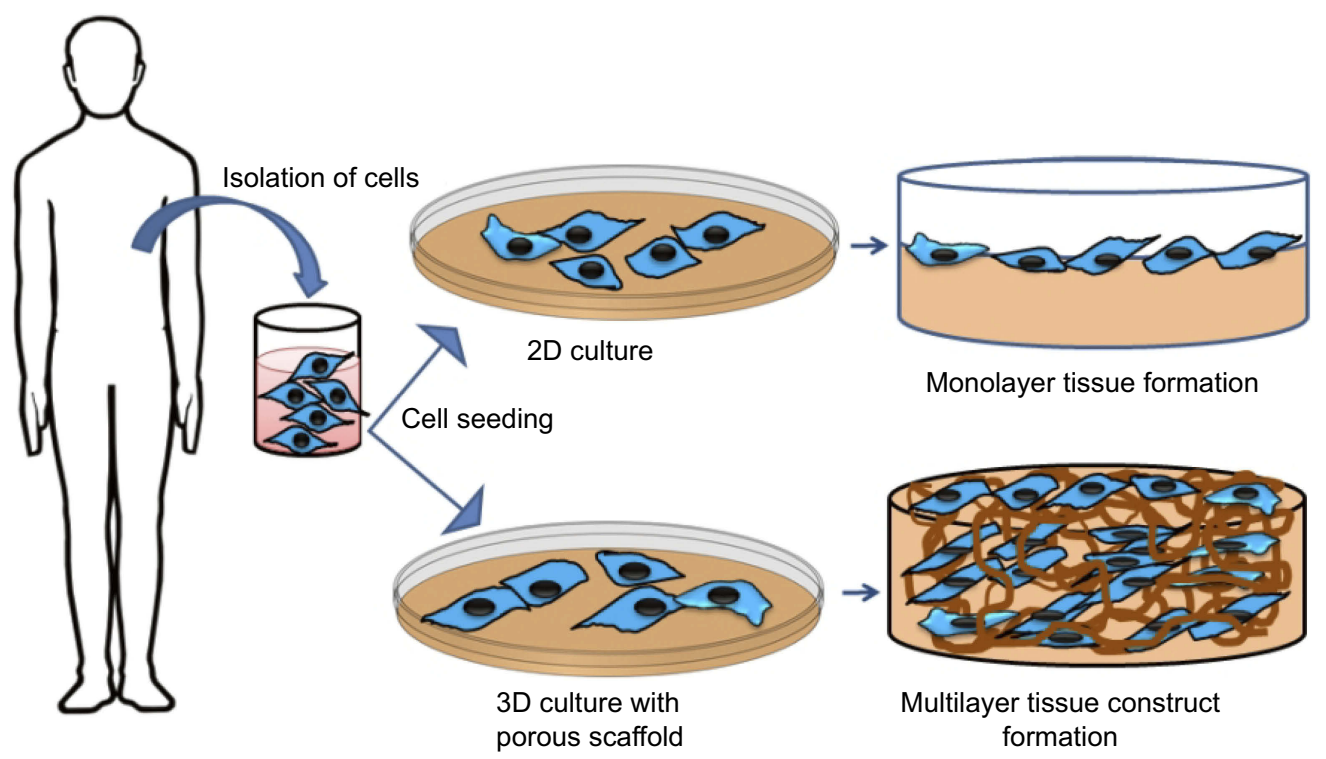

Figure 2 Schematic representation of the 2D and 3D scaffolds.

morphology, intracellular-extracellular protein production, receptor organization, gene expressions, etc. ${ }^{13,14}$ Moreover, 2D scaffold-based tissue engineering faces concerns regarding mass transfer, whereby the availability of nutrients and oxygen is limited to the cells. This is due to the high surface to mass ratio of scaffolds which constraints the growth, proliferation, and differentiation of the tissue construct. Another concern is the development of multilayer tissue structures for the formation of complete organ (liver, kidney, heart, etc.), which has high ratios of surface area to mass and has a variety of similar cells present in the same scaffold which are needed in a specific cellular environment. ${ }^{3}$ Having the advantage of mimicking the functions of a live tissue, 3D tissue culture bridges the gap between in vitro cell culture and real tissue. ${ }^{15,16}$

In $3 \mathrm{D}$ cell culture, a cellular microenvironment is created in the cell-cell or cell-ECM interactions, which mimics the normal real-life scenario. Accordingly, cell growth, differentiation, and proliferation will be supported in this system. A 3D tissue culture offers a wider platform for therapeutic investigations and drug discovery. It provides a physiologically relevant morphology, a normal cellular microenvironment, and the possibility of co-culture of a variety of cells. ${ }^{17,18}$ Various approaches are available for the preparation of $3 \mathrm{D}$ culture such as forced floating, hanging drop, agitation-based methods, microfluidic cell culture platforms, matrices, and scaffolds. ${ }^{19}$ The medical advancements lead to the development of $3 \mathrm{D}$ cultures utilizing matrices and scaffolds to create "closer to in vivo" organo-typic cultures. These $3 \mathrm{D}$ cultures are used in investigations regarding cellular differentiation, drug discovery, tumorigenesis, gene-protein expressions, signaling pathways, cell physiology, cellular proliferation, apoptosis, cell motility, microenvironmental conditions, etc. $^{16,20,21}$

The choice of scaffolds for 3D cell culture depends on the function and cell types. Scaffold's properties vary based on polymer concentration, ligand density, pore size, structure, flexibility, stiffness, etc. Owing to their biocompatibility, natural polymers such as collagen, gelatin, elastin, silk fibroin, chitosan (CS), chitin, fibrin, and fibrinogen are extensively used for preparing 3D scaffolds. Synthetic polymers such as polylactic acid (PLA), poly(glycolic acid), polyhydroxyalkanoate, and poly (lactic-co-glycolic acid) (PLGA) were also utilized in the preparation of 3D scaffold due to their easily adapting porosity, degradation time, and mechanical characteristics. ${ }^{22,23}$ In a 3D cell culture, the scaffold provides support for cells to maintain the biophysical and biomechanical interaction by acting as the ECM. It creates a biologically active microenvironment and surface architecture that is favorable for a variety of cells to grow, differentiate and proliferate by providing the optimal required conditions. ${ }^{24,25}$ Ultimately, 3D scaffold could replace the 2D scaffold system whereby the latter has no actual similarity with the in vivo system. Apart from this, 3D scaffold-based tissue engineering has displayed an enhanced RNA expression and gene regulation possibly due to the cell-cell interaction in the 3D environment, which could be an effective and valuable future tool in 
various fields such as drug discovery, cancer therapy, and regenerative medicine. ${ }^{2,26,27}$ The different types of scaffold materials and their advantages are listed in Table 1.

Some of the limitations of 3D cell culture involve the requirement of extended time, challenges in microscopy, inadequate mass transfer of nutrients and oxygen due to the diffusion limited environment, and maintenance of aseptic conditions. Moreover, the 3D culture prepared as spheroids has limitations during analysis such as spatial analysis concerns due to the structure, requirement of fixation for histology analysis, reliability of tissue construct in terms of drug response, etc. ${ }^{42}$ Besides, 3D culture using fibers and porous scaffolds also possess limitations in co-culturing certain cells in a spatially controlled

Table I Types of scaffold materials, the preparation modes, and their responses to specific cells or tissues

\begin{tabular}{|c|c|c|c|c|}
\hline Scaffold & Type of cells or tissue & $\begin{array}{l}\text { Preparation } \\
\text { method }\end{array}$ & Response & Ref. \\
\hline $\begin{array}{l}\text { Chitosan, fibroin, } \\
\text { hydroxyapatite }\end{array}$ & $\begin{array}{l}\text { Human osteosarcoma cells } \\
\text { (SAOS-2) }\end{array}$ & Freeze-drying & $\begin{array}{l}\text { Excellent biocompatibility, improved cell growth and } \\
\text { enhanced osteogenic differentiation. }\end{array}$ & 28 \\
\hline $\begin{array}{l}\text { Silk fibroin, poly- } \\
\text { ethylene } \\
\text { terephthalate }\end{array}$ & Mesenchymal stem cells (MSCs) & $\begin{array}{l}\text { Plasma-induced } \\
\text { acrylic acid graft } \\
\text { polymerization }\end{array}$ & $\begin{array}{l}\text { Enhanced proliferation and adhesion of MSCs. Observed } \\
\text { some inhibition to cell growth due to the toxicity of } \\
\text { scaffold. }\end{array}$ & 29 \\
\hline $\begin{array}{l}\text { Chitosan, gelatin, } \\
\text { silicon dioxide }\end{array}$ & $\begin{array}{l}\text { Human osteosarcoma cells } \\
\text { (MG63) }\end{array}$ & Lyophilization & $\begin{array}{l}\text { Nontoxic scaffold, fast cell adhesion, good proliferation, } \\
\text { fast differentiation of osteoblasts. }\end{array}$ & 30 \\
\hline Chitosan, carbon & Neonatal rat heart cells & Precipitation & Good biocompatibility, enhanced electrical signaling. & 31 \\
\hline $\begin{array}{l}\text { Poly(l-lactide-co- } \\
\text { glycolide), } \\
\text { Bionate }{ }^{\circ} \text { 80A UR }\end{array}$ & Rat cardiomyoblasts $(\mathrm{H} 9 \mathrm{C} 2)$ & Electrospinning & $\begin{array}{l}\text { Supported adhesion and proliferation, good mechanical } \\
\text { properties, spontaneous synchronous contractility. }\end{array}$ & 32 \\
\hline Poly(I-lactic acid) & $\begin{array}{l}\text { Cardiovascular progenitor cells } \\
\text { from mouse embryonic stem } \\
\text { cells (ESCs) }\end{array}$ & $\begin{array}{l}\text { Phase-separation } \\
\text { process }\end{array}$ & $\begin{array}{l}\text { Supported cell survival, differentiation and integration; } \\
\text { cardiac tissue formation. }\end{array}$ & 33 \\
\hline $\begin{array}{l}\text { Gelatin } \\
\text { methacrylamide }\end{array}$ & Hepatocarcinoma cells (HepG2) & $\begin{array}{l}\text { Sequential fiber } \\
\text { deposition (3D } \\
\text { printing) }\end{array}$ & $\begin{array}{l}\text { Construct with desired stiffness, shape, and reliability. } \\
\text { High viability }(>97 \%) \text { and expression of liver functions. }\end{array}$ & 34 \\
\hline Gelatin & $\begin{array}{l}\text { Human embryonic stem cell } \\
\text { derived cardiomyocytes (hESC- } \\
\text { CMs) }\end{array}$ & Uniaxial stretching & $\begin{array}{l}\text { Elongation, better alignment, and improved electrome- } \\
\text { chanical signals. Exhibited foetal-like cardiomyocyte } \\
\text { phenotype. }\end{array}$ & 35 \\
\hline $\begin{array}{l}\text { Nanofibrillated } \\
\text { cellulose }\end{array}$ & Human chondrocytes (HNC) & 3D bioprinting & Biocompatible material and enhanced growth. & 36 \\
\hline Collagen & $\begin{array}{l}\text { Differentiated human neuro- } \\
\text { blastoma cell line (SH-SY5Y) }\end{array}$ & - & $\begin{array}{l}\text { Promote glial cell attachment, migration, and highly } \\
\text { orientated process outgrowth neuron repair. }\end{array}$ & 37 \\
\hline Collagen, chitosan & $\begin{array}{l}\text { Human dermal fibroblast in vivo } \\
\text { rabbit models }\end{array}$ & Freeze-drying & $\begin{array}{l}\text { Good biocompatibility. Improved fibroblast infiltration } \\
\text { from the surrounding tissue. }\end{array}$ & 38 \\
\hline Silk fibroin-keratin & Vascular dermal tissue & Freeze-drying & $\begin{array}{l}\text { Improved thermal, degradation and mechanical proper- } \\
\text { ties. Higher protein expression and enhanced functional } \\
\text { proliferation. }\end{array}$ & 39 \\
\hline $\begin{array}{l}\text { Silk sericin, poly } \\
\text { (vinyl alcohol) }\end{array}$ & Feline fibroblast cell line (HFFI) & Freeze-drying & Biocompatible and biodegradable polymer. & 40 \\
\hline $\begin{array}{l}\text { Hydroxyapatite, } \\
\text { graphene, chitosan }\end{array}$ & $\begin{array}{l}\text { Rabbit bone marrow stromal } \\
\text { cells (rBMSCs) }\end{array}$ & $\begin{array}{l}\text { Self-assembly and } \\
\text { lyophilisation }\end{array}$ & $\begin{array}{l}\text { High cell viability, better cell density, increased cellular } \\
\text { attachment and extended proliferation and differentiation } \\
\text { of osteoblasts. }\end{array}$ & 41 \\
\hline
\end{tabular}


manner, regulation of the signaling in the system, limitation on perfusion, etc. Advanced microfluidic 3D cultures have solutions for many of these concerns of $3 \mathrm{D}$ tissue engineering. ${ }^{43}$

A scaffold-free approach also has been explored in the engineering of skin, periosteum, myocardium, periodontium, and corneal epithelium tissue sheets, where the cells were cultured as a monolayer, with conditions to promote ECM production to form a robust tissue sheet. ${ }^{44-50}$ Recently, such a scaffold-free approach was used to generate engineered corneal stromal tissue sheets for replacement of scarred corneal tissue. ${ }^{51}$ When transplanted into corneal stromal pockets, this engineered tissue sheets were incorporated into surrounding tissues and became transparent without eliciting any adverse reaction which strongly supports the potential of this stromal constructs in regenerative therapy. In contrast, in the case of inkbased 3D printing, soft materials in the form of printable inks are articulated from various molecular, polymeric, or particulate species. This scaffold preparation is obtained by the desired flow behavior designed by the factors such as ink's viscosity, surface tension, shear yield stress, shear elastic, and loss moduli. Light- and ink-based 3D printing methods can control the fabrication of soft matter that has tunable mechanical, electrical, and other functional properties. ${ }^{52}$ Generally, the engineered 3D scaffolds cannot completely represent the complexity of real natural extracellular matrices, the microenvironment with cellcell interactions, cellular organization, and the functions of living tissues. Decellularized ECM turns out as an excellent unique choice in terms of composition and topology, resident cells interactions, and microenvironment. ${ }^{53,54}$ Pati et $a l,{ }^{55}$ investigated the concept of decellularized ECM with bioinks, including adipose, cartilage, and heart tissues. The bioprinting of cell-laden constructs in the decellularized ECM showed crucial cues for cells engraftment, survival, and long-term function with high cell viability and functionality.

\section{Nano in scaffolds}

Scaffolds act as ECM which create a suitable platform for cellular interactions, nutrient-gas transport, removal of toxic metabolites, etc. In normal cells, the ECM follows a range of nanotopographical patterns to support the formation of tissue, whereas, in bone tissues, ECM appears in the form of different nanostructures. When introduced to 3D scaffolds, nanomaterials with the size range of $100 \mathrm{~nm}$ can mimic the natural tissue conditions by enhancing tissue growth, differentiation, proliferation, cellular signaling, etc. ${ }^{56-58}$ Moreover, 3D scaffolds which consist of nanofibers, nanotubes, and nanoparticles, which are made of polymers such as PLA, PLGA, polyvinyl alcohol (PVA), and polycaprolactone (PCL) found to be effective in influencing the fate of stem cells. Besides polymers, carbon materials offer a great choice of nanomaterials for tissue engineering due to their biocompatibility and incredible mechanical strength. ${ }^{59-61}$ Carbon-based scaffolds provide unique features that are compatible with the natural ECM and were found to enhance the cell-cell interaction and normal cellular functions in tissue engineering. In addition, these scaffolds with specific nanotopographical structures can influence the survival of the cells and their functions. ${ }^{62}$

\section{Graphene and its derivatives in cell and tissue engineering}

Carbon-based nanomaterials function as an excellent platform for the development of 3D tissue engineering scaffolds. Carbon materials of different dimensions such as fullerenes, carbon nanotubes, and graphite were successfully employed in many tissue engineering investigations due to their mechanical stability. ${ }^{63-65}$ These carbon nanomaterials are considered as a physical analog of ECM components such as collagen fibers due to their similar dimensions. ${ }^{65-67}$

Graphene family incorporates a number of derivatives with contrasts within the structure and properties such as graphene oxide (GO), reduced graphene oxide (RGO), graphene quantum dots (GQDs), graphene nanosheets, monolayer graphene, and few layer graphene. Graphene has exceptional physical, chemical, and mechanical properties such as exceptional Young's modulus ( 1.0 TPa), large surface area $\left(2,630 \mathrm{~m}^{2} \mathrm{~g}^{-1}\right)$, great intrinsic mobility $\left(200,000 \mathrm{~cm}^{2} \mathrm{v}^{-1} \mathrm{~s}^{-1}\right)$, good thermal conductivity $(\sim 5,000$ $\left.\mathrm{Wm}^{-1} \mathrm{~K}^{-1}\right)$, high optical transmittance $(\sim 97.7 \%)$, and excellent electrical conductivity. ${ }^{68-72}$ Furthermore, the ease of modification and functionalization enables the utilization of biocompatible graphene nanomaterials for wider applications in the health care industry. ${ }^{73-77}$ The biocompatibility enables the use of graphene nanomaterials in drug/gene delivery, bioimaging, biosensing, antibacterial, anticancer, and tissue engineering applications. ${ }^{78-83}$

Graphene is the basic structure of graphite, which is made up of a single layer of carbon atoms. Figure 3 displays the structure of graphene, GO and RGO. Oxidation 


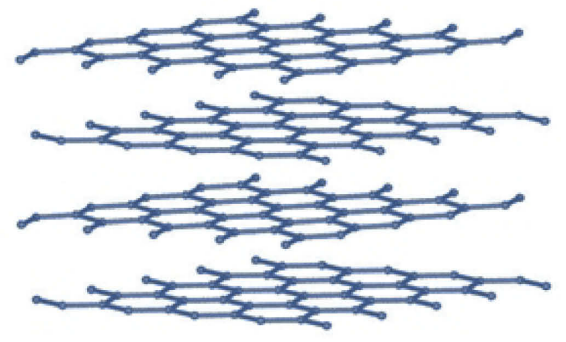

Graphite

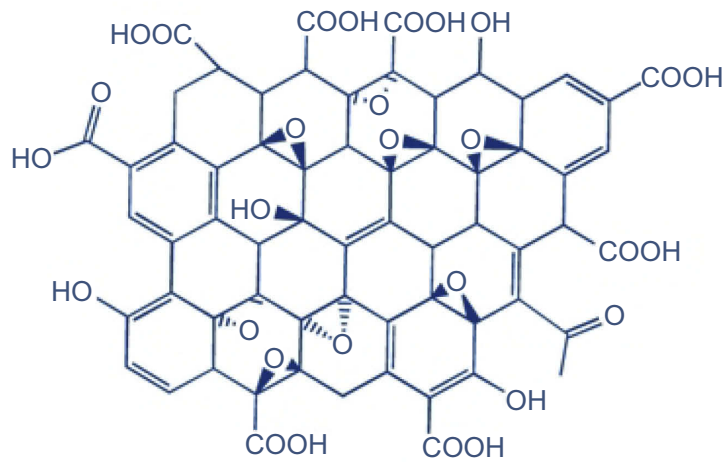

Graphene oxide

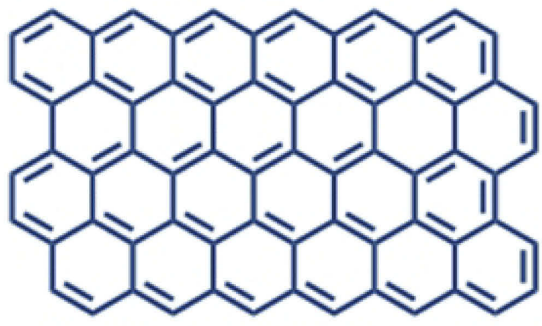

Graphene

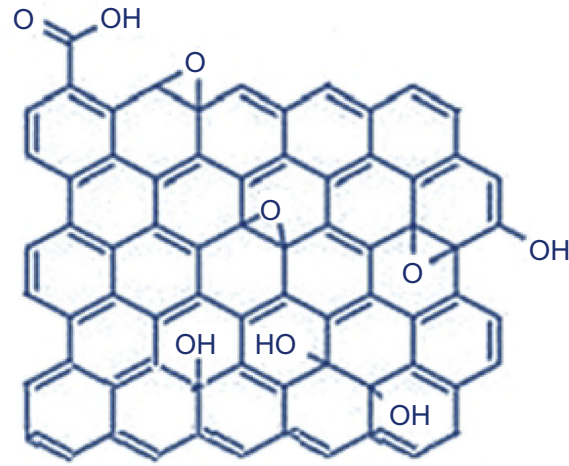

Reduced graphene oxide

Figure 3 Structure of graphite, graphene, graphene oxide (GO), and reduced graphene oxide (RGO).

of graphite results in the synthesis of GO. GO is reduced by reducing agents to create RGO through a variety of reduction processes. GO has an outstanding aqueous processability, amphiphilicity, ease of surface functionalization, surface enhanced Raman scattering property, and fluorescence quenching ability. These fascinating properties of GO are derived from its unique chemical structures $\left(\mathrm{sp}^{2}\right.$ carbon domains surrounded by $\mathrm{sp}^{3}$ carbon domains) and oxygen containing hydrophilic functional groups. ${ }^{84,85}$ The latter, RGO, which is synthesized by the reduction of GO includes diverse reduction methods such as hydrothermal, chemical, photocatalytic, electrochemical, solvothermal, sonochemical, phytochemical (green chemistry), or multistep reduction. Reduction process incorporates changes in the structure, electrical conductivity, hydrophilicity, color, and in the side functional groups. During the reduction process, GO undergoes thermal deoxygenation, chemical deoxygenation, restoration of long-range conjugated structures, and healing of defects. ${ }^{86-88}$

\section{Graphene-based scaffolds}

Graphene-based nanomaterials act as excellent components for scaffold materials due to their unique electrical/ thermal conductivity, mechanical stability, chemical composition, porous structure, biocompatibility, bioadhesion property, etc. ${ }^{89-93}$ The preparation of graphene uses either top-down or bottom-up approaches. ${ }^{94,95}$ Integration of graphene components has excitingly enhanced the cytocompatibility of biomaterials by osteointegration, stem cell differentiation into variety of cells, improved neuronal growth and branching, which boost the production of vascular endothelial growth factor (VEGF)/pro-angiogenic gene for cardiac repair. ${ }^{96-99}$ Table 2 describes the response of different graphene scaffold materials in terms of various sizes, composition as well as physical appearance. The more recent graphene derivative, RGO foams, are employed in various tissue engineering investigations such as neural, bone, heart, dental, and stem cells. Generally, graphene is synthesized either by liquid exfoliation, ball milling, spray coating, chemical vapor deposition (CVD), reduction of GO, etc. ${ }^{68,87,100-102}$

\section{Design and development of scaffold}

Compared to the 2D scaffolds investigated on a variety of cells, 3D-graphene scaffolds showed an excellent response in the proliferation and differentiation of cells for developing tissue constructs in various organs (heart, liver, and kidney) and nervous system (spinal cord and brain). 
Table 2 Types of graphene nanomaterials used in different tissue engineering applications

\begin{tabular}{|c|c|c|c|}
\hline Scaffold & Type of cells or tissue & Response & Ref. \\
\hline GO & Neurons & $\begin{array}{l}\text { Excellent biocompatibility, facilitates long-term nerve regeneration in vivo. Scaffold } \\
\text { showed enhanced neurite sprouting and angiogenic restoration. }\end{array}$ & 103 \\
\hline Nano GO & Adipose stem cells & Appropriate biodegradation with a lower inflammatory reaction in in vivo analysis. & 104 \\
\hline Nano GO & Bone cells & Improved thermal stability, cytocompatibility, osteo-bioactivity, and biodegradability. & 105 \\
\hline Graphene & Neural stem cells & $\begin{array}{l}\text { Neural proliferation, stimulation, induced differentiation of stem cells, degradability, and } \\
\text { implantable neuronal networks. }\end{array}$ & 106 \\
\hline $\begin{array}{l}\text { Graphene } \\
\text { nanoflakes }\end{array}$ & Mesenchymal stem cells (MSCs) & $\begin{array}{l}\text { Cell viability, proliferation and significant upregulation of both osteogenic and neuro- } \\
\text { genic gene expression. }\end{array}$ & 107 \\
\hline $\begin{array}{l}\text { Single layer } \\
\text { Graphene }\end{array}$ & Human MSCs (hMSCs) & $\begin{array}{l}\text { Graphene accelerated cell adhesion to the substrate without affecting cell proliferation. } \\
\text { Graphene promotes osteogenic differentiation by protein upregulation. }\end{array}$ & 108 \\
\hline $\begin{array}{l}\text { RGO } \\
\text { nanomesh }\end{array}$ & $\begin{array}{l}\text { Human neural stem cells } \\
\text { (hNSCs) }\end{array}$ & $\begin{array}{l}\text { Good chemical stability, excellent cell differentiation, good proliferation, and differen- } \\
\text { tiation to neural cells. }\end{array}$ & 109 \\
\hline $\begin{array}{l}\text { GO and } \\
\text { RGO } \\
\text { hydrogel }\end{array}$ & Myoblasts $(\mathrm{C} 2 \mathrm{Cl} 2)$ & $\begin{array}{l}\text { RGO hydrogel exhibited superior proliferation, myogenic differentiation and increased } \\
\text { myogenic gene expression compared with GO hydrogel. }\end{array}$ & 110 \\
\hline $\begin{array}{l}\text { GO fiber } \\
\text { mat }\end{array}$ & $\begin{array}{l}\text { Human osteoblast cell line } \\
\text { (SAOS-2) }\end{array}$ & High tensile strength, modulus and enhanced cell proliferation. & 111 \\
\hline $\begin{array}{l}\text { RGO } \\
\text { hydrogel }\end{array}$ & Cardiomyocytes & Improved cell viability, proliferation, and maturation. & 112 \\
\hline RGO & $\begin{array}{l}\text { Wister rat peritoneal macro- } \\
\text { phage cells }\end{array}$ & Antibacterial, antifungal, and biocompatible to macrophage cells. & 113 \\
\hline RGO & $\begin{array}{l}\text { Fibroblasts (NIH-3T3) and } \\
\text { macrophages (RAW 264.7) }\end{array}$ & Biocompatible, biodegradable, and bioactive. & 114 \\
\hline GO, RGO & $\begin{array}{l}\text { Human dental pulp stem cells } \\
\text { (DPSCs) }\end{array}$ & Greater cell growth, differentiation, and improved protein adsorption. & 115 \\
\hline $\begin{array}{l}\text { Few layer } \\
\text { graphene }\end{array}$ & Cardiac cells (HL-I) & Improved cell-cell coupling and better electrical conductivity. & 116 \\
\hline Graphite & $\begin{array}{l}\text { Rat embryo fibroblast cell (REF } \\
\text { 52) }\end{array}$ & $\begin{array}{l}\text { Flexibility, good electrical conductivity, tunable mechanical properties, ease of functio- } \\
\text { nalization, and better cell adhesion. }\end{array}$ & 117 \\
\hline $\begin{array}{l}\text { Graphene } \\
\text { monolayer }\end{array}$ & Dental pulp stem cells (DPSC) & $\begin{array}{l}\text { Mineralization and differentiation of cells, upregulated gene/protein expression sup- } \\
\text { porting osteogenic differentiation and skeletal morphogenesis. }\end{array}$ & 118 \\
\hline $\begin{array}{l}\text { Graphene } \\
\text { nanosheets }\end{array}$ & Nerve cells $(\mathrm{PCI} 2)$ & Higher electrical and mechanical properties with enhanced bioactivity. & 119 \\
\hline RGO foams & Rat bone MSCs (rBMSCs) & $\begin{array}{l}\text { Increased mineralization, collagen deposition, cell proliferation, and in vivo bone defect } \\
\text { healing. }\end{array}$ & 114 \\
\hline
\end{tabular}

Abbreviations: GO, graphene oxide; RGO, reduced graphene oxide.

Graphene-based 3D scaffolds with anticipated features could contribute in the cell proliferation through the micro/nanoporous structure which enables the smooth transportation of cell-cell or cell-ECM interactions through different cellular signals (chemical and electrical signals). The scaffold topography will vary based on the preparation methods and conditions. Based on the micro/ nano-architectures used, the desired features (electrical, optical, mechanical, chemical, or electrochemical properties) of the graphene materials will vary. Thus, the 
fabrication of graphene 3D scaffold has to be planned according to its utilization and the type of cells to be cultured. ${ }^{106,120-122}$

\section{Fabrication of graphene scaffold}

The preparation of graphene-based 3D scaffolds involves different synthesis approaches such as covalent amide interactions by mixing functionalized graphene nanostructures with natural or synthetic polymers through gas foaming technique (ammonium bicarbonate as the porogen), graphene with different ratios of polymers and metal ions directed CVD process, self-assembled graphene foam (GF) by hydrothermal synthesis, chemical etching, etc. ${ }^{123-125}$ The scaffold fabrication process follows various approaches such as solvent casting, gas foaming, phase separation, melt molding technique, emulsification, freeze-drying/lyophilization, electrospinning, microfluidic technique, photopolymerization, micromolding, and bioprinting. Based on the synthesis approach, the characteristics of the scaffold will also vary. ${ }^{126-130}$

Solvent casting involves casting of an organic polymer with crosslinkers and salts; thereafter the material is subjected to solvent evaporation and dissolution of the salt molecules in water. The possibility of the presence of salt residue in the scaffold is the demerit of this fabrication technique. ${ }^{131}$ Introduction of GO and graphene platelets to PLA was observed to enhance the tensile strength and Young's modulus. Moreover, the nanocomposite prepared in the solvent casting approach exhibited control in gas permeability (oxygen and nitrogen) through the films, which is a supporting feature to be utilized in tissue engineering applications. ${ }^{132}$ In another investigation, the introduction of graphene nanomaterial to PLA resulted in changes in the morphology, surface topography, wettability, surface charge, and mechanical properties. The analysis of nanocomposite in mouse embryo fibroblasts showed good biocompatibility with an enhancement in cell adhesion and proliferation supporting faster tissue regeneration; however, a decrease in the platelet adhesion and activation was also observed.

Gas foaming is another novel technique to prepare 3D nanofibrous scaffolds. Foaming agents such as sodium borohydride were introduced to the multi-layered polymeric mat and allowed for gas production by capillary action. This formed gas is then removed by washing with methanol or water. The inter-porosity of the sheets permits the diffusion of nutrients and signaling products between the layers. ${ }^{133}$ Yang et al, ${ }^{134}$ developed a porous GO modified poly(propylene-carbonate) 3D scaffold utilizing supercritical carbon dioxide by the supercritical gas foaming technique. The scaffold displayed excellent dimension stability and the features of final pore depended on the saturation conditions of $\mathrm{CO}_{2}$. The influence of saturation temperature and pressure on the morphology of scaffold is shown in Figure 4.

Phase separation is another technique to develop 3D scaffolds. Jing et al, ${ }^{135}$ developed a composite scaffold using GO and polyurethane by thermal phase separation. Based on the concentration of GO, a change was observed in the pore size and the surface morphology of the nanocomposite. An increase in the concentration of GO leads to a decrease in the pore diameter, an increase in the surface roughness and elastic moduli. However, there was no cytotoxic response observed for the nanocomposite when tested in 3T3 fibroblast culture.

In the melt molding technique, the components of the scaffold are mixed and treated with high temperature followed by processing of the melted solution to predesigned molds. Sayyar et al, ${ }^{136}$ developed a 3D scaffold made of PCL and graphene by melt extrusion technique which created 50\% more mechanically stable scaffolds with good biocompatibility. Another investigation used the same components: PCL with GO and PCL with RGO which created two different types of 3D scaffolds by compression molding and was tested against osteoblast. The combination of GO and PCL exhibited better biocompatibility compared to RGO and PCL combination scaffold. Interestingly, RGO nanoparticle incorporated scaffold showed enhanced cellular proliferation, cell-cell interactions, and higher mineralization, collectively improving the bone cell growth. ${ }^{137}$

Emulsification is another approach in the preparation of tissue engineering scaffolds based on hydrogels. ${ }^{138}$ This method possesses a high control over the pore size and structure of the scaffold. ${ }^{139}$ Chen et al, ${ }^{140}$ recently developed a biocompatible macroporous nanocomposite made of GO and PVA by the emulsification method. Once the emulsion is prepared with PVA and GO in the solution, the addition of catalysts triggers polymerization to create the micro/macroporous structure which could act as carriers of cells or drug for various applications.

Freeze-drying/lyophilization is the removal of frozen solvents and the bound water molecules. Generally, frozen solvent is removed through sublimation and the bound water molecules through desorption. The preparation of scaffolds through freeze-drying has an influence on the 

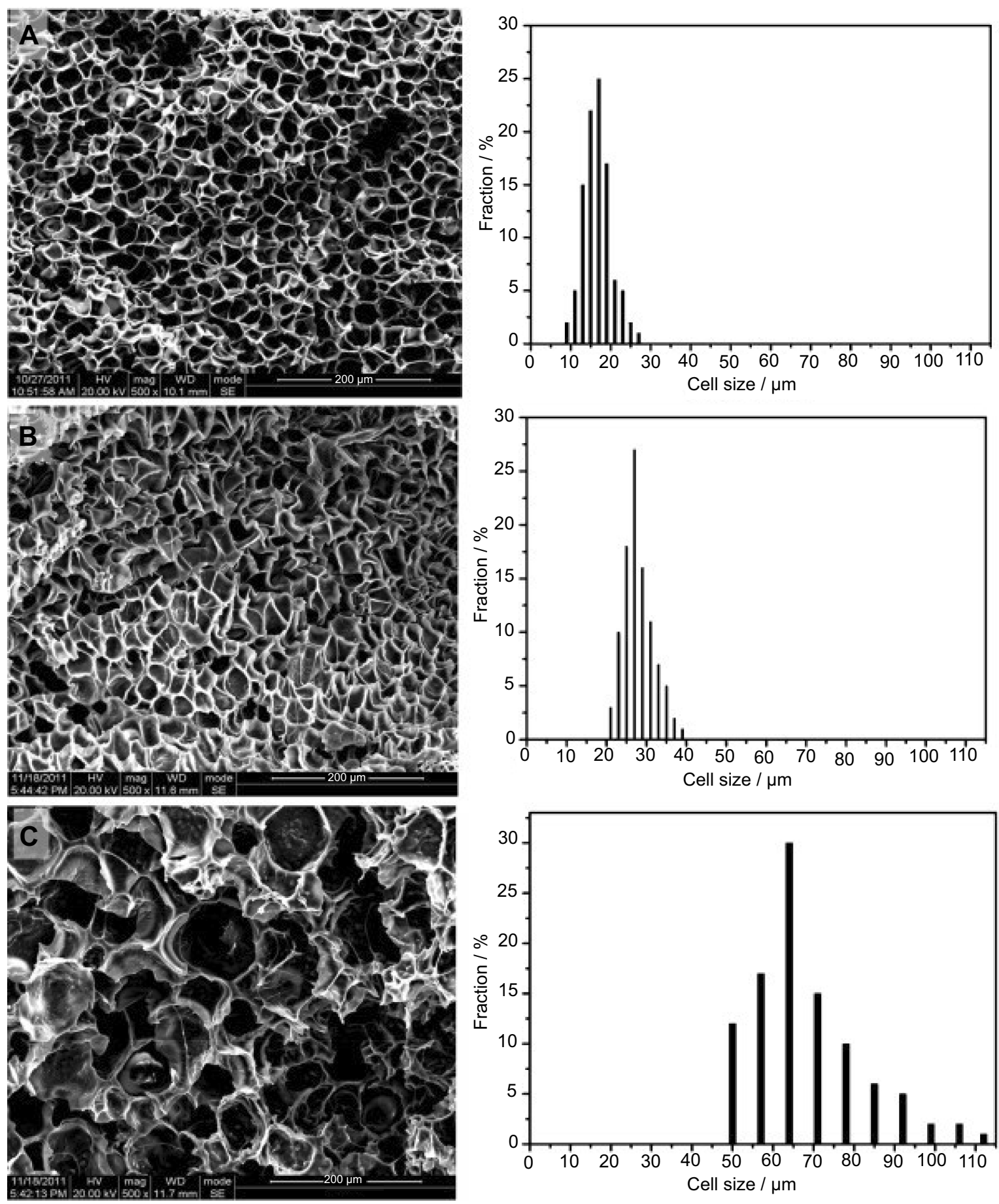

Figure 4 The effect of saturation temperature on the pore morphology and its distribution (in terms of diameter) of GO modified poly(propylene-carbonate) foams: (A) $20^{\circ} \mathrm{C}$ for $2 \mathrm{hrs}$, (B) $50^{\circ} \mathrm{C}$ for $2 \mathrm{hrs}$, and (C) $80^{\circ} \mathrm{C}$ for $2 \mathrm{hrs}$.

Notes: Reprinted from Yang G, Su J, Gao J, Hu X, Geng C, Fu Q. Fabrication of well-controlled porous foams of graphene oxide modified poly (propylene-carbonate) using supercritical carbon dioxide and its potential 1820 tissue engineering applications. J Supercrit Fluids. 2013;73:I-9. Copyright 2013, with permission from Elsevier. ${ }^{134}$

structure and pore size of the scaffold. Subsequently, the pore size has proven effects on the cell growth and attachment. ${ }^{141,142}$ Micro/nano-architectures made of graphene-polymer were prepared to utilize freeze-drying. ${ }^{143}$ The freeze-dried porous structure of scaffold using GO, hydroxyapatite (HA) nanoparticles and CS is shown in Figure $5 \mathrm{~A},{ }^{41}$ whereas the formation of uniform-sized macropores is displayed in Figure 5B. ${ }^{144}$

Electrospinning method involves the preparation of nanofibers utilizing electric field and a conductive solution 
A
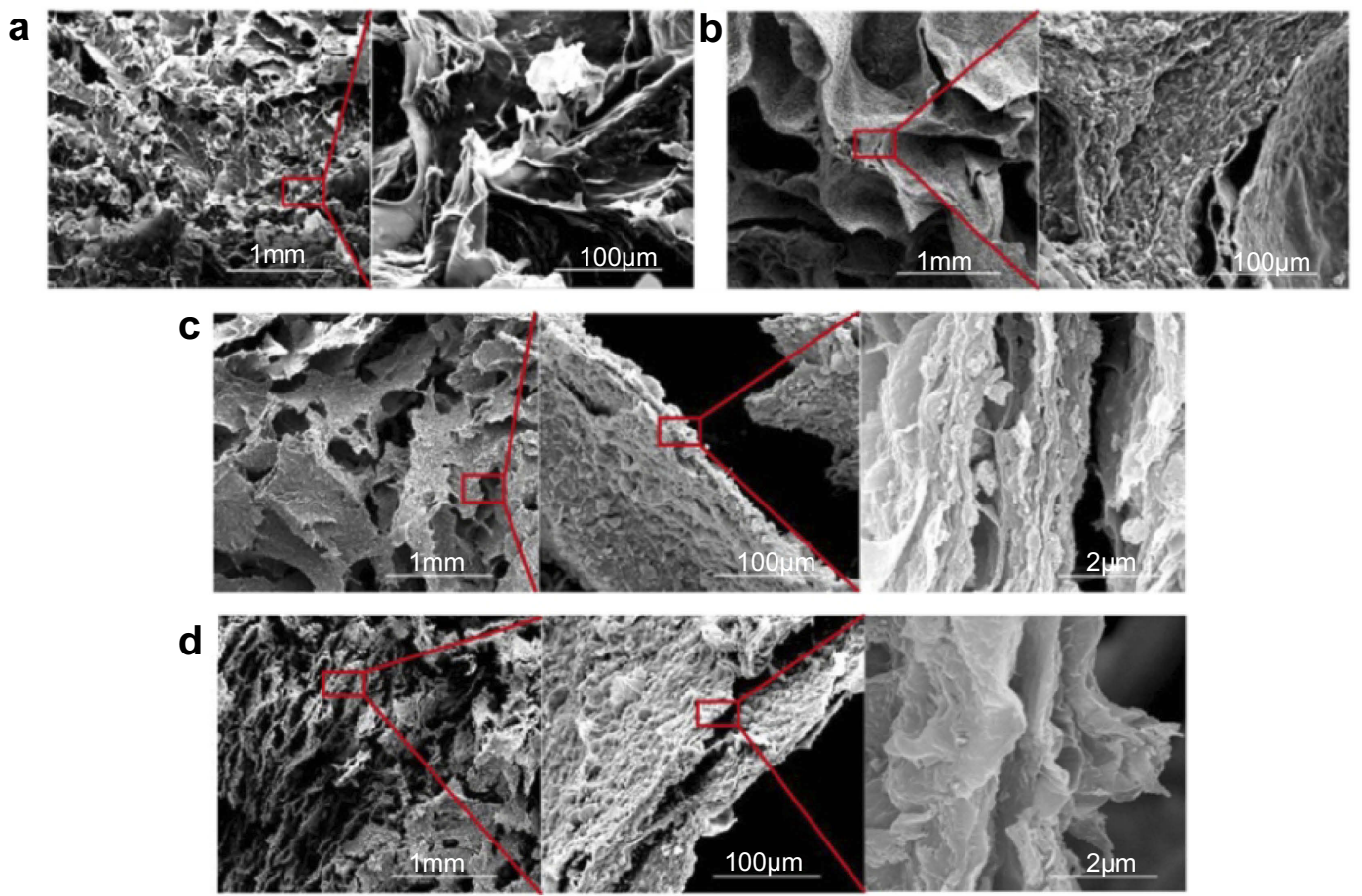

B
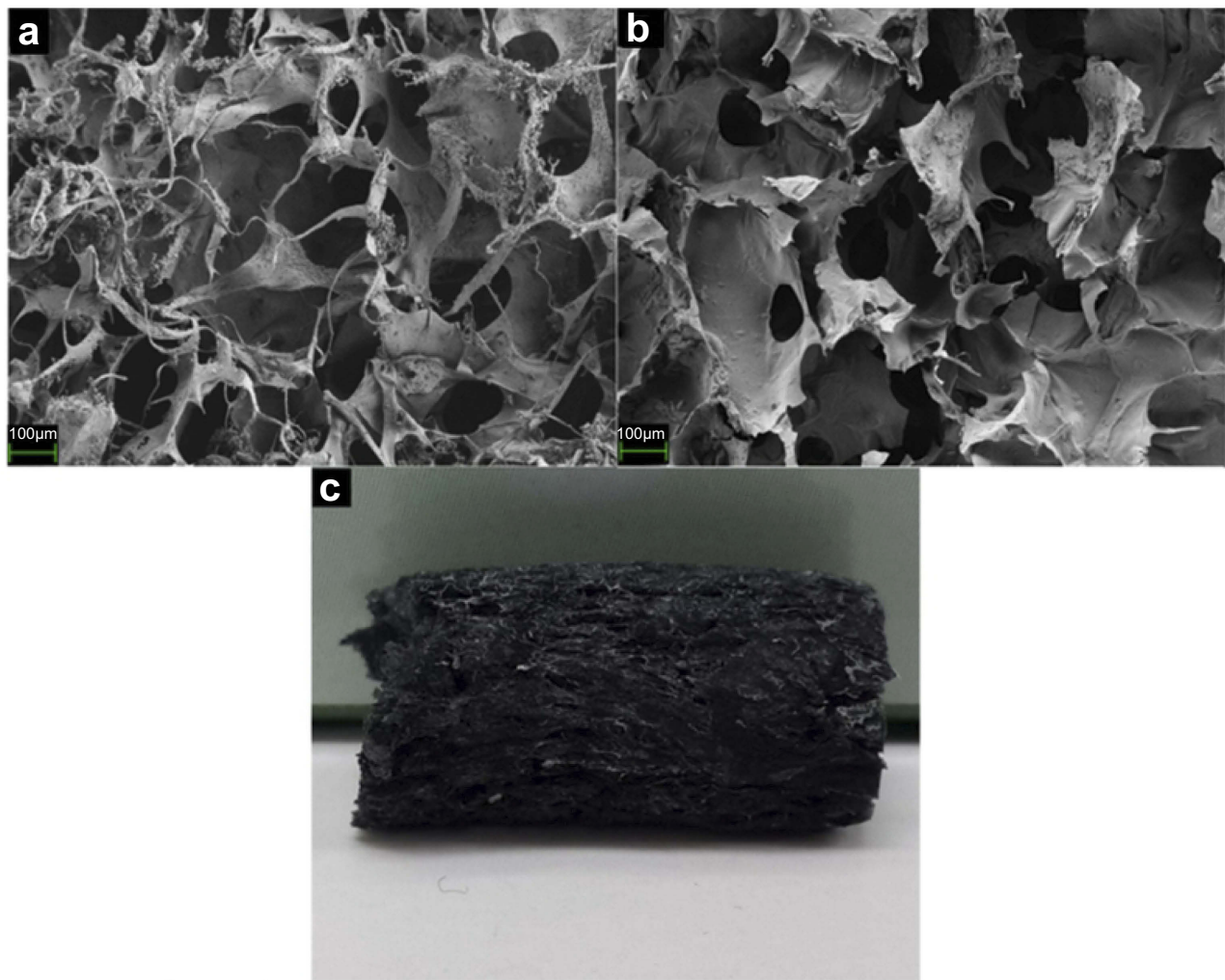

Figure 5 (A) SEM images of 3D GO hydrogels prepared with different ratios of cross-linking agent (G) with reducing agent (N) [(a) G/N-0/0, (b) G/N-0/l, (c) G/N-3/0, and (d) G/N-3/I)]. (B) Images of CS-HA-GO composite scaffold: (a) and (b) FESEM images showing the morphology, (c) photograph of CS-HA-GO composite scaffold. Notes: Figure A reprinted from Yu P, Bao R-Y, Shi X-J, Yang W, Yang M-B. Self-assembled high-strength hydroxyapatite/graphene oxide/chitosan composite hydrogel for bone tissue engineering. Carbohydr Polym. 2017;155:507-515. Copyright 2017, with permission from Elsevier. ${ }^{41}$ Figure B reprinted from Unnithan AR, Park CH, Kim CS. Nanoengineered bioactive 3D composite scaffold: a unique combination of graphene oxide andnanotopography for tissue engineering applications. Compos Part B Eng. 2016;90:503-5II. Copyright 2016, with permission from Elsevier. ${ }^{144}$ 

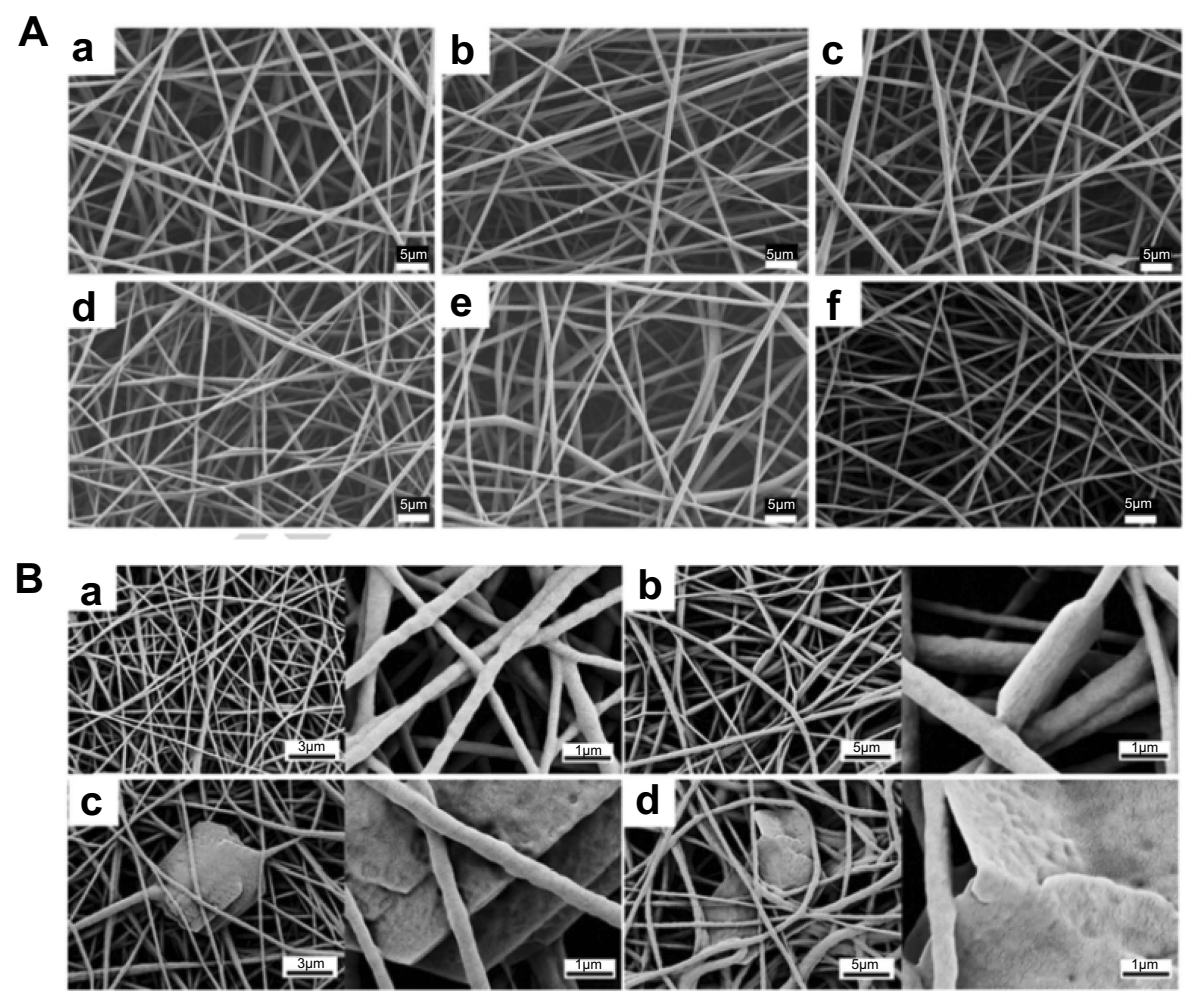

Figure 6 (A) SEM micrographs of electrospun nanofibers made of PLA and GO combinations: (a) PLA, (b) PLA/GO (I\%), (c) PLA/GO (2\%), (d) PLA/GO-g-PEG (I\%), (e) PLA/GO-g-PEG (2\%), and (f) PLA/GO-g-PEG (5\%). (B) Images of electrospun scaffolds using TPU and GO combination (a) TPU, (b) $0.5 \%$ GO, (c) I\% GO, and (d) $2 \%$ GO. The presence of beading due to $\mathrm{GO}$ in the fibrous structure can be seen in the high magnification images of the composites.

Notes: Figure A reprinted from Zhang C, Wang L, Zhai T, Wang X, Dan Y, Turng L-S. The surface grafting of graphene oxide with poly (ethylene glycol) as a reinforcement for poly (lactic acid) nanocomposite scaffolds for potential tissue engineering applications. J Mech Behav Biomed Mater. 2016;53:403-4I3. Copyright 20I6, with permission from Elsevier. ${ }^{145}$ Figure B reprinted from Jing X, Mi H-Y, Salick MR, Cordie TM, Peng X-F, Turng L-S. Electrospinning thermoplastic polyurethane/graphene oxide scaffolds for small diameter vascular graft applications. Mater Sci Eng C. 2015;49:40-50. Copyright 2015, with permission from Elsevier. ${ }^{146}$

deposited on the charged surface. The synthesis of nanofibrous scaffold using PLA by incorporating GO and polyethylene glycol (PEG) using electrospinning technique also exhibited excellent morphological, thermal, mechanical, and wettability properties. ${ }^{145}$ The concentration of PLA was kept constant and the loading level of GO-PEG varied from $1 \%$ to $10 \%$ to optimize the conditions to create nanofibres. Based on the electrical conductivity, the viscosity of the prepared solution; the filler concentration; and the diameter of fibers varied as shown in Figure 6A. The cytocompatibility analysis of this electrospun scaffold with Swiss mouse NIH 3T3 cells exhibited nontoxic response with enhanced cell attachment and growth. In a similar experiment using thermoplastic polyurethane (TPU), the increased concentration of GO created some level of aggregation (Figure $6 \mathrm{~B}$ ). The in vitro biocompatibility analysis on 3T3 fibroblasts and human umbilical vein endothelial cell (HUVEC) culture showed that an increased level of GO concentration leads to cell death, which could be due to the aggregating nature of fibers which induces stress on the cells. ${ }^{146}$
Bioprinting is a novel method of generating geometrically defined structures in 3D. This technique could considerably control the physiological appearance and functions of the developed scaffold. Moreover, compared to the classical scaffold preparations, bioprinting has an advantage of excellent reproducibility and control over the scaffold structure. ${ }^{147,148}$ Wang et al, ${ }^{149}$ developed a 3D scaffold using graphene and PCL via a screw-assisted additive bio-manufacturing bioprinter system (3D Discovery, RegenHU, Villaz-St-Pierre, Switzerland). PCL-graphene nanocomposite was initially heated, cooled, and introduced to the bioprinter to fabricate the scaffold. The size, shape, and distribution of pores in the scaffold were controlled by the input parameters. Analysis of the biocompatibility on human adipose-derived stem cells exhibited good cellular attachment and no toxicity response. Similarly, Vijayavenkataraman et $a 1,{ }^{150}$ used PCL-RGO bioprinted scaffold for peripheral nerve injury repair. Compared to PCL scaffolds, the in vitro evaluations of P12 cells on PCL-RGO exhibited enhanced cell proliferation and neural differentiation of P12 cells in these scaffolds. 
Micromolding and photolithography are similar techniques used to prepare nanoscaffolds laden with cells. ${ }^{151}$ These techniques were utilized for preparing the scaffolds based on hydrogels. 3D scaffolds made of graphene hydrogels are used in bone tissue, nerve tissue, cardiac, and stem cell engineering. ${ }^{152-155}$ The various preparation techniques of graphene-based scaffolds, their advantages and disadvantages are listed in Table 3.

In summary, based on the preparation methodology, the properties of scaffold will vary tremendously. Since many factors and parameters are involved, the intended scaffold has to be engineered or designed based on the desired application.

\section{Design criteria and characterization of the scaffold}

Scaffold is a 3D template used for the initial cell attachment and subsequent growth, proliferation, differentiation, extension, and tissue formation both in vitro and in vivo. The structure, architecture, and physiochemical properties regulate the quality of newly grown tissue. ${ }^{165}$ Critical factor to be considered is the incorporation of an artificial vascular system, to improve mass transport of oxygen and nutrients into the interior of the scaffold for proper cellular growth. ${ }^{166}$ Other design criteria in the preparation of scaffold comprise of biological, mechanical, and physicochemical parameters. Biological factors involve the

Table 3 Different fabrication methods of graphene-based scaffolds, their advantages, and disadvantages

\begin{tabular}{|c|c|c|c|}
\hline $\begin{array}{l}\text { Scaffold pre- } \\
\text { paration } \\
\text { method }\end{array}$ & Advantages & Disadvantages & Ref. \\
\hline Freeze-drying & $\begin{array}{l}\text { Low pressure processing, stable structure, thermal stability, apt hydrophilicity, } \\
\text { biocompatibility, good porosity, and improved morphology to stimulate cell } \\
\text { growth. Good porosity and interconnectivity enable easy microvasucularizations. }\end{array}$ & Some inflammatory responses. & 156,157 \\
\hline $\begin{array}{l}\text { lce segrega- } \\
\text { tion-induced } \\
\text { self-assembly } \\
\text { (ISISA) }\end{array}$ & $\begin{array}{l}\text { ISISA process showed unidirectional control of the morphology (by freezing in } \\
\text { nitrogen liquid) and illustrates the in-situ incorporation of biological entities which } \\
\text { provides hierarchy and functionality to the resulting materials. Improvement in } \\
\text { number of cell and collagen infiltration, blood vessels, ambient conditions that for } \\
\text { the growth of neuronal axons within the scaffold. No evidence of atrophy, } \\
\text { inflammation, or fibrosis were detected in peripheral organs. }\end{array}$ & $\begin{array}{l}\text { A significant reduction in cells } \\
\text { positive for vimentin. Macrophages } \\
\text { are influenced by the presence of } \\
\text { graphene nanomaterials. }\end{array}$ & 158 \\
\hline Solvent casting & $\begin{array}{l}\text { Suitable for creating scaffolds with uniform pore size. Enables controlled gas perme- } \\
\text { ability (oxygen and nitrogen) through the films, enhances tissue engineering applica- } \\
\text { tions. The in vitro analysis in mouse embryo fibroblasts displayed faster tissue } \\
\text { regeneration with good biocompatibility, cell adhesion enhancement ,and proliferation. }\end{array}$ & $\begin{array}{l}\text { Presence of salt residues in the } \\
\text { scaffold. }\end{array}$ & 131,132 \\
\hline Gas foaming & $\begin{array}{l}\text { The inter-porosity of the scaffold permits diffusion of nutrients and signaling } \\
\text { products between the layers. Exceptional dimension stability depends on the } \\
\text { saturation conditions. Enhanced adhesion, proliferation, and differentiation }\end{array}$ & $\begin{array}{l}\text { Non-biodegradability and in vivo } \\
\text { toxicity due to oxidative potential. }\end{array}$ & 159 \\
\hline Melt moulding & $\begin{array}{l}\text { Mechanically stable scaffolds with good biocompatibility, enhanced cellular prolif- } \\
\text { eration, accelerated growth, differentiation, cell-cell interactions proliferation of } \\
\text { stem cells, and higher mineralization. }\end{array}$ & $\begin{array}{l}\text { Cellular uptake mechanisms not } \\
\text { clear. }\end{array}$ & 160,161 \\
\hline Emulsification & $\begin{array}{l}\text { Hydrogels based scaffolds which have high control over the pore size and struc- } \\
\text { ture of the scaffold. Excellent drug carriers, improved cell adhesion and suitable } \\
\text { environments for tissue engineering. }\end{array}$ & Multiple drug loading not possible & 162 \\
\hline Electrospinning & $\begin{array}{l}\text { Simple and low-cost equipment, easy scale-up possibility of outstanding morpho- } \\
\text { logical, thermal, mechanical, and wettability properties. Good biocompatibility, } \\
\text { enhanced cell attachment and growth. } \\
\text { Suitable for static and dynamic cell culture protocols. }\end{array}$ & $\begin{array}{l}\text { Limited cell infiltration in dense } \\
\text { structures. Increased graphene } \\
\text { concentration causes stress in cer- } \\
\text { tain cell types. }\end{array}$ & 163,164 \\
\hline Bioprinting & $\begin{array}{l}\text { Geometrically defined structures. Control over morphology and functions of the } \\
\text { developed scaffold. Excellent reproducibility. Good cell viability, cellular attach- } \\
\text { ment proliferation, maturation, and no toxicity response. }\end{array}$ & $\begin{array}{l}\text { Controlled cell distributions and } \\
\text { vascularization. }\end{array}$ & 112 \\
\hline
\end{tabular}


selection of biocompatible and bioactive materials which support the initial adhesion, cellular growth, proliferation, and differentiation of the required tissue. Mechanical parameters ensure the stability of scaffold materials. Meanwhile, the physiochemical factors in scaffold fabrication are determined by many factors. The external geometry of the scaffold indicates the micro/macrostructure and interconnectivity of the 3D scaffold. Another factor is the surface property which includes the surface energy, charge, surface area, etc. Porosity, pore size, and pore distribution are other design criteria. Interface adherences between cells and scaffolds as well as biocompatibility are other parameters to be considered. In addition, degradation kinetics of the scaffold is another important specification that constraints the design. Mechanical competence of the scaffold against compressive and tensile strength also has to be considered in the design of scaffold. ${ }^{138,144,165}$

\section{Characterization of graphene scaffold}

The 3D graphene scaffolds are characterized based on their morphology, chemical composition, mechanical stability, biocompatibility, etc. Morphological characterization of the scaffolds normally performed via scanning electron microscopy), transmission electron microscopy, and/or atomic force microscopy imaging. ${ }^{120,167-169}$ The determination of porosity and surface area is carried out by BrunauerEmmett-Teller (BET) analysis where nitrogen gas is adsorbed on the solid surface to analyze the porous nature of the scaffold. For example, BET analysis of a 3D scaffold made of graphene-augmented inorganic nanofibres exhibited $85-95 \%$ oriented porosity. ${ }^{170}$ The presence of graphene nanomaterial enables the use of Raman spectroscopy for the characterization of scaffold to analyze the formation of different chemical bonds and to study the structure of graphene nanomaterials in the nanocomposite. ${ }^{171} \mathrm{X}$-ray photoelectron spectroscopy (XPS) is a surface-sensitive analytical technique for analyzing the energy of the photoelectrons (50 $2,000 \mathrm{eV}$ ) that are emitted when a surface is bombarded with $\mathrm{X}$-rays in a vacuum chamber. In graphene studies, XPS evaluates the chemical shifts in carbon and validates the elemental, chemical, and electronic structure. ${ }^{172}$ The reduction of GO to RGO in a graphene scaffold can be determined via XPS analysis by comparing the ratio of carbon and oxygen elements in these two graphene derivatives. ${ }^{173,174}$ Mechanical characterization of the scaffolds can be carried out by evaluating Young's modulus, elastic modulus, flexural modulus, tensile strength, maximum strain, and load-bearing capacity, etc. $^{22}$ Electrical stimulation and photostimulation studies are other techniques conducted to evaluate the properties of scaffold in response to electric field and light. ${ }^{98,175}$ In order to evaluate the biocompatibility of the graphene scaffold, different cell viability assays such as lactate dehydrogenase, reactive oxygen species (ROS), Alizarin Red staining, and fluorescent staining assays have been conducted. $^{62,171,176}$

\section{Cellular microenvironment (cells and growth factors)}

Cellular microenvironment is the local surrounding which interacts with the cells by means of chemical and physical signals, and thus it holds an imperative role in tissue engineering. Biochemical, structural, electrical, biomechanical, and spatial factors could influence the cellular growth in the in vivo-like $3 \mathrm{D}$ culture. ${ }^{177}$ Engineered microenvironments can control the cell-cell and cellECM interactions in a 3D system in a favorable manner and thus regulate many cellular functions like growth, differentiation, migration, gene expression, protein synthesis, apoptosis, etc. In-depth understanding of the complexity and heterogeneity of the cellular environment could contribute toward the design of novel drug delivery systems and cell-based assays. Different 3D culture forms such as hanging drop plates, microwell plates, cellular microarrays, and microfluidic devices become crucial in determining the efficiency and toxicity of novel potential drugs. ${ }^{178,179}$ Mechanotransduction is another process where the mechanical properties of the extracellular environment induce cellular responses, leading to changes in the cell behavior and structure. This includes many factors such as biochemical signaling, spatial patterning of the cells, rigidity of the scaffold as well as shear/tension/ stretch forces experienced by the cells in the scaffold. ${ }^{180}$ Mechanotransduction found to be efficient in cardiac tissue engineering for optimal recruitment, migration, mechanical integration of progenitor cells to myocardium and its differentiation. In hamster ovary cells, mechanotransduction had an effect on the gene regulation of chromatin. Other studies in 3D culture displayed the effect of mechanotransduction over the expression of integrinmediated protein for controlling the cellular attachments, where in the case of solid tumor cells it affects the migration of cells. ${ }^{181-183}$ Regulating the synchronization of physical, chemical, and mechanical cues that control the cell function in the 3D construct can result in valuable outcomes closely related to in vivo conditions irrespective 
of the size or structure of the system. However, cellular microenvironment functions in a two-way interactive mode which ensure the efficiency of the natural cell functions for the regenerative purpose. ${ }^{184}$

\section{Graphene 3D scaffolds in tissue engineering}

The success of tissue engineering depends on the biological communication between cells and the scaffold, which is controlled by the scaffold material and its characteristics. In order to induce cell adhesion, proliferation, and activation, scaffold material has to be biocompatible and competent to interact with the cells. The morphology, mechanical stability, and degradation kinetics of the scaffold material should match with the new tissue/organ to be engineered. Factors such as scaffold architecture, porosity (pore size and its distribution) and availability of surface area for cellular attachment control the outcome of the tissue regeneration process. ${ }^{23,152}$

Being an excellent biomaterial, graphene materials satisfy the design criteria and characteristics of an ideal scaffold component. Graphene nanomaterials based scaffolds have been employed in various medical applications including tissue engineering for the past few decades. The revolution of tissue engineering from $2 \mathrm{D}$ to $3 \mathrm{D}$ cultures introduced many concerns, which were suppressed by the excellent performance of graphene-based scaffolds. In the current scenario, graphene-based 3D scaffolds are used for tissue engineering of heart, bone, cartilage, nerve, skin, liver, etc. ${ }^{185-188}$ Furthermore, the utilization of undifferentiated stem cells cultured with suitable signals in the 3D culture could be developed into specific organ-based tissue, which supports the field of regenerative medicine by replacing the damaged organs. Owing to this, advances in stem cell-based tissue engineering have a huge reliance on graphene-based scaffolds, specifically in terms of inducing signals for cell differentiation and proliferation. ${ }^{189,190}$ Enhancement in the mechanical properties, excellent electrical conductivity, high optical transmittance, biodegradability, and its antibacterial property encourage further utilization of graphene-based scaffolds for 3D mammalian tissue culture. ${ }^{106,186}$

The developments in 3D scaffolds in terms of bioprinting could even create prevascularized tissue constructs with complex microarchitecture. ${ }^{191-193}$ The investigations on cardiac cell culture utilizing graphene nanomaterials based scaffold rely on the factors such as electrical conductivity, flexibility, and mechanical stability. ${ }^{116}$
Conductive 2D scaffolds utilizing RGO or GO in combination with gelatin methacryloyl (GelMA) as hydrogel forms were investigated by seeding with cardiomyocytes. The RGO sheets based scaffolds displayed enhanced cellcell interaction through their interaction with proteins either by charge-based electrostatic interaction or $\pi-\pi$ interaction. Compared to the GelMA and GO-GelMA scaffolds, the RGO-GelMA scaffold exhibited spontaneous synchronous beating activity with cardiomyocytes, homogenous cell networks with cell-cell junctions, good electrical conductivity, etc. RGO-GelMA based scaffold presented a good response to adhesion, proliferation, and maturation of cardiac cells. The promising future of the tissue construct utilizing this RGO 2D scaffolds leads to the development of graphene-based 3D scaffolds for cardiac cells. ${ }^{112}$ In cardiac engineering, graphene-based 3D scaffolds have shown excellent capability in providing electrical stimulation in an extracellular environment, which are the unique features required for cultivating cardiac cells that have inherent electroactivity. In this study, GF modified with $0.02 \%$ gelatin $/ 0.005 \%$ fibronectin was used as the scaffold. For analysis, HL-1 cells derived from mouse atrial tumors were used. An extracellular electrical response was observed corresponding to the calcium transient measurements in the cells which produced beating characteristics on the cells. This indicates that the use of graphene 3D scaffold is an ideal ECM for culturing cardiac cells. ${ }^{116}$ Similarly, mouse embryonic stem cells were cultured on graphene $3 \mathrm{D}$ scaffolds made of PCL nanofibers prepared by electrospinning. The cells were seeded on the graphene-PCL 3D scaffold enabling the differentiation of embryonic stem cells to cardiomyocytes, and the conductive properties were analyzed. In addition, to understand the efficiency of the scaffold in cardiac tissue engineering, variations in the protein expressions and the beating characteristics of the cells corresponding to calcium transient were also evaluated. ${ }^{194}$ In another study, graphene-based material has also shown enhanced activity in the bone formation and structuraltextural properties of a biomaterial. This modified graphene displayed pro-osteodifferentiation capability on the implants and scaffold materials by simple surface modifications. ${ }^{195,196}$

Combining RGO with natural bone mineral, nano-HA (nHA), which has excellent properties such as osteoconductivity and osteoinductivity, resulted in the design of a selfassembled biomimetic 3D scaffold suitable for bone tissue engineering. The porous 3D scaffold made by Nie et al, ${ }^{114}$ 
was investigated on in vivo bone repair efficiency, accentuating the impacts of the graphene composite on in vivo bone cell growth and mineralization. Interestingly, compared to RGO, the RGO-nHA based biomimetic 3D scaffold showed enhanced cell proliferation, alkaline phosphatase (ALP) activity, and excellent osteogenic potential. In vitro studies on rat bone mesenchymal stem cells and in vivo studies on New Zealand white rabbits highlighted the biocompatibility and bone repairing ability of the $3 \mathrm{D}$ scaffold. The timely histological analysis of the bone repair process was investigated utilizing various techniques as shown in Figure 7. For the studied duration of 6 weeks, more new tissue and cells were observed both in RGO and RGO-nHA scaffolds, however, the RGO-nHA scaffold showed new bone matrix, collagen, and osteoid tissue. Moreover, the proliferation of cells was found to be more in the RGO-nHA scaffold compared to RGO alone. The evaluation of bone cells on the sixth week displayed RGO-
nHA scaffolds with matured bone matrix ready for remodeling, whereas RGO exhibited only few ossification tissues.

In another study, 3D scaffold was prepared by combining $\mathrm{GO}$ with $\mathrm{CS}$ to analyze the potential of bone tissue engineering. To prepare the 3D culture bioconstruct, 3T3E1 mouse preosteoblasts were seeded on the surface of $\mathrm{CS}, \mathrm{CS} / \mathrm{GO} \quad(0.5 \mathrm{wt} \%)$, and $\mathrm{CS} / \mathrm{GO} \quad(3 \mathrm{wt} \%)$. Subsequently, cells were allowed to diffuse through the porous scaffold with the required culture conditions. Compared with the cell cultures on CS scaffold, the cells on CS/GO scaffold resulted in metabolically active cells with no toxicity response in the tested period of 7 days, which indicated excellent biocompatibility of the scaffold. Moreover, 3T3E1 cell proliferation found to be dependent on the concentration of GO in the scaffold with its maximum proliferation obtained at $3 \mathrm{wt} \%$ of $\mathrm{GO}$. The presence of GO improved the mechanical characteristics, pore
A

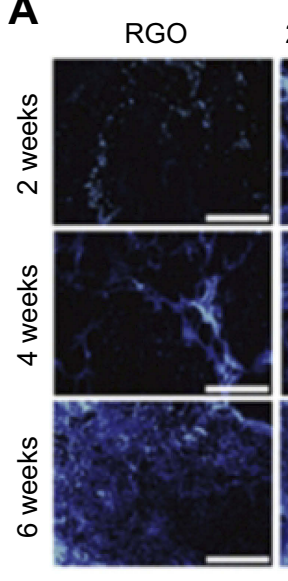

D

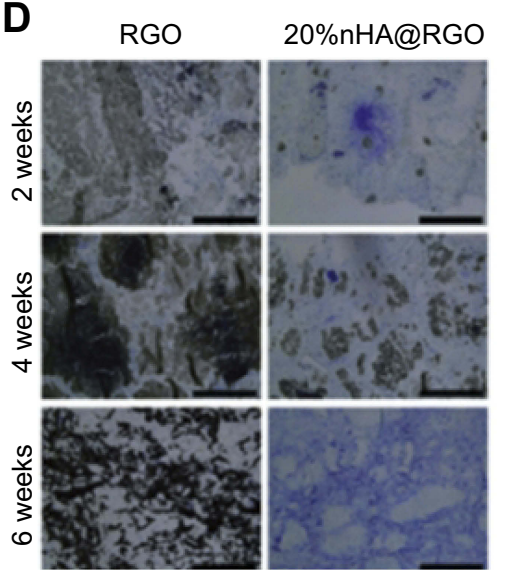
20\%nHA@RGO

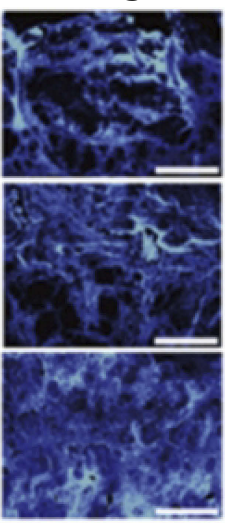

B

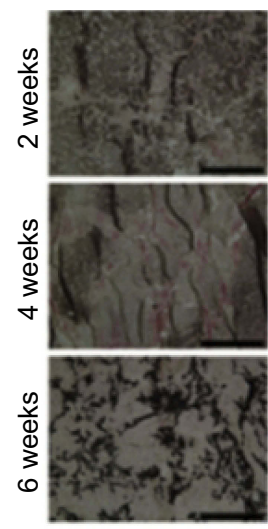

E

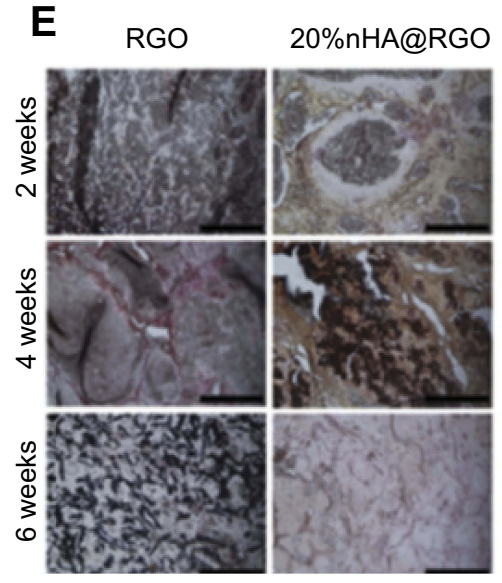

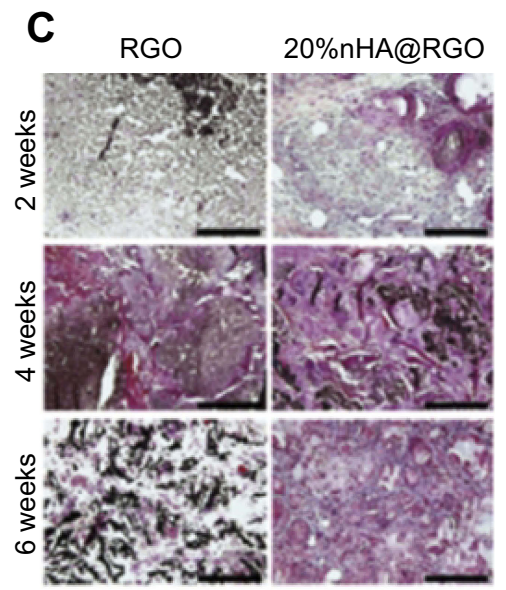

$\mathbf{F}$

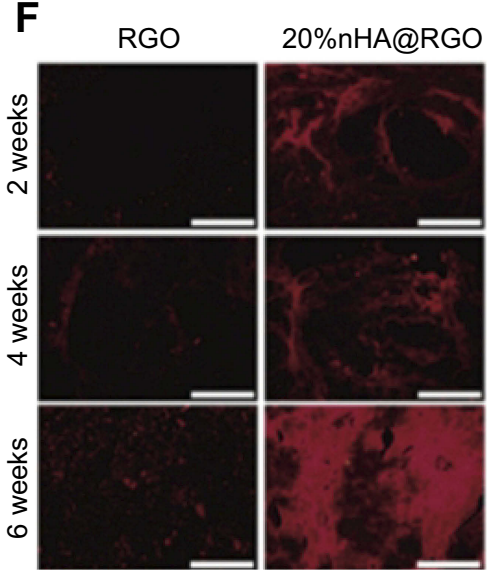

Figure 7 Histological analysis for in vivo bone defect repair by different staining methods: (A) DAPI, (B) Goldner, (C) Masson's trichrome staining, (D) Toluidine blue, (E) ALP, and (F) OCN. The size bar is $200 \mu \mathrm{m}$ (all the images). (A color image can be viewed online).

Notes: Reprinted from Nie W, Peng C, Zhou X, et al. Three-dimensional porous scaffold by self-assembly of reduced graphene oxide and nano-hydroxyapatite composites for bone tissue engineering. Carbon. 2017;116:325-337. Copyright 2017, with permission from Elsevier. ${ }^{197}$ 
formation, and bioactivity of the scaffold and thus promoted the possibilities for in vitro and in vivo bone tissue engineering. 198

Another similar scaffold was prepared by Saravanan et al, ${ }^{199}$ by incorporating gelatin $(\mathrm{GN})$ to $\mathrm{GO}$ and $\mathrm{CS}$. This 3D scaffold was prepared by freeze-drying approach and tested using rat osteoprogenitor cells. GO/CS/GN scaffold showed better physiochemical properties when tested for properties such as biodegradation, wettability, protein adsorption, and biomineralization, which all favored application toward bone tissue engineering. Additionally, it exhibited the potential to differentiate mouse mesenchymal stem cells into osteoblasts. The swelling property of the scaffold significantly improved with the addition of GO, probably due to the hydrophilic functionalities present in GO. Fibronectin and vinculin are essential proteins created by osteoblasts for assisting the attachment between cells and the scaffolds. The initial protein adsorption on biomaterials is a crucial factor for the successful biomaterial implants, where the addition of GO enhanced protein adsorption property of the 3D scaffold by providing its hydrophilic side functional groups and improving the surface area of the scaffold. The in vitro cytotoxicity and cell viability of the scaffold resulted in the expression of osteoblast differentiation marker genes such as ALP, type-1-collagen, and osteocalcin. The in vivo osteogenic ability is assessed by the healing process of tibial bone defects in rat models, where it got filled with $0.25 \% \mathrm{GO} / \mathrm{CS} / \mathrm{GN}$ scaffold. The growth of new bone in the defect area proved the biocompatibility and osteogenic nature of GO/CS/GN scaffold. As shown in Figure 8, the histological assessment was performed to determine the presence of formation of new bone in the rat tibial defect. ${ }^{199}$

Having very limited regenerative capacity of cartilages, the preparation of tissue engineering scaffolds for cartilages is critically important. Liao et al, ${ }^{200}$ designed a $3 \mathrm{D}$ scaffold CSMA/PECA/GO using GO in combination with methacrylated chondroitin sulfate and poly(ethylene glycol) methyl ether- $\varepsilon$-caprolactone-acryloyl chloride. The scaffold has macropores and interconnective structure. Moreover, the scaffold showed cartilage like biodegradation profile and mechanical properties. Additionally, the 3D scaffold exhibited excellent adhesion and proliferation of cartilage cells. From the biocompatible response of the scaffold in $3 \mathrm{~T} 3$ cells which was implanted subcutaneously into a rat animal model, it was found that the scaffold underwent complete degradation in 2 weeks with no signs of hematoma and purulent activity. In vivo analysis on rabbit model was also conducted to analyze the scaffold's potential in healing a critical osteochondral defect, whereby a recovered subchondral bone and hyaline cartilage were observed. Besides these remarkable findings, the excellent electrical conductivity of the scaffold also makes it a suitable platform for bone, heart, and nerve tissue engineering. 200

As for skin tissue engineering, the key strategy to be considered while preparing a scaffold is vascularization. It could either be done by altering the physiochemical properties of the scaffold, biological activation of scaffold using growth factors or by creating prevascularized skin substitutes by seeding the scaffolds with vessel-forming cells. $^{201}$ In alignment with this, electrospun scaffolds made of GO in combination with PLGA and collagen (Col) were found to be successful in regenerating the skin tissues for wound healing treatments. The $3 \mathrm{D}$ interconnected pore structure and suitable hydrophilic/hydrophobic nature required for the cellular adhesion are some of the critical factors affecting the tissue development. Loading of GO and Col regulated a favorable role in the regeneration of skin and thus influenced the proliferation and migration of dermal fibroblasts. ${ }^{202}$

Li et al, ${ }^{203}$ prepared a 3D scaffold for skin tissue engineering, utilizing GF scaffold loaded with bone marrowderived mesenchymal stem cells (MSCs) to improve skin wound healing by its high water retention capability to maintain the moisture of wound. GF being a continuous and porous structure exhibited excellent biocompatibility and promoted the growth and proliferation of MSCs. The seeded MSCs controlled the upregulation of VEGF and basic fibroblast growth factor, thus initiated neovascularization. The antiscarring effect was observed as a result of the regulation of transforming growth factor-beta 1 and alpha-smooth muscle actin together with an increase of TGF- $\beta 3$. In a nutshell, the GF-MSCs scaffold promoted the healing process with reduced scarring and enhanced vascularization. GF can provide topographical, chemical, and electrical cues in a scaffold to create an environment for the regeneration of skin tissue in the presence of favorable cellular microenvironment, where GF can induce the differentiation of MSCs to specific lineages (as skin cells). Figure 9 shows the in vivo imaging and details where the wound closure is observed better with GF-MSCs as compared with GF alone and control. ${ }^{203}$

Another 3D scaffold developed by Shin et al, ${ }^{204}$ was made of GO-GelMA hydrogel, seeded with cells which presented excellent cellular spreading and alignment with 

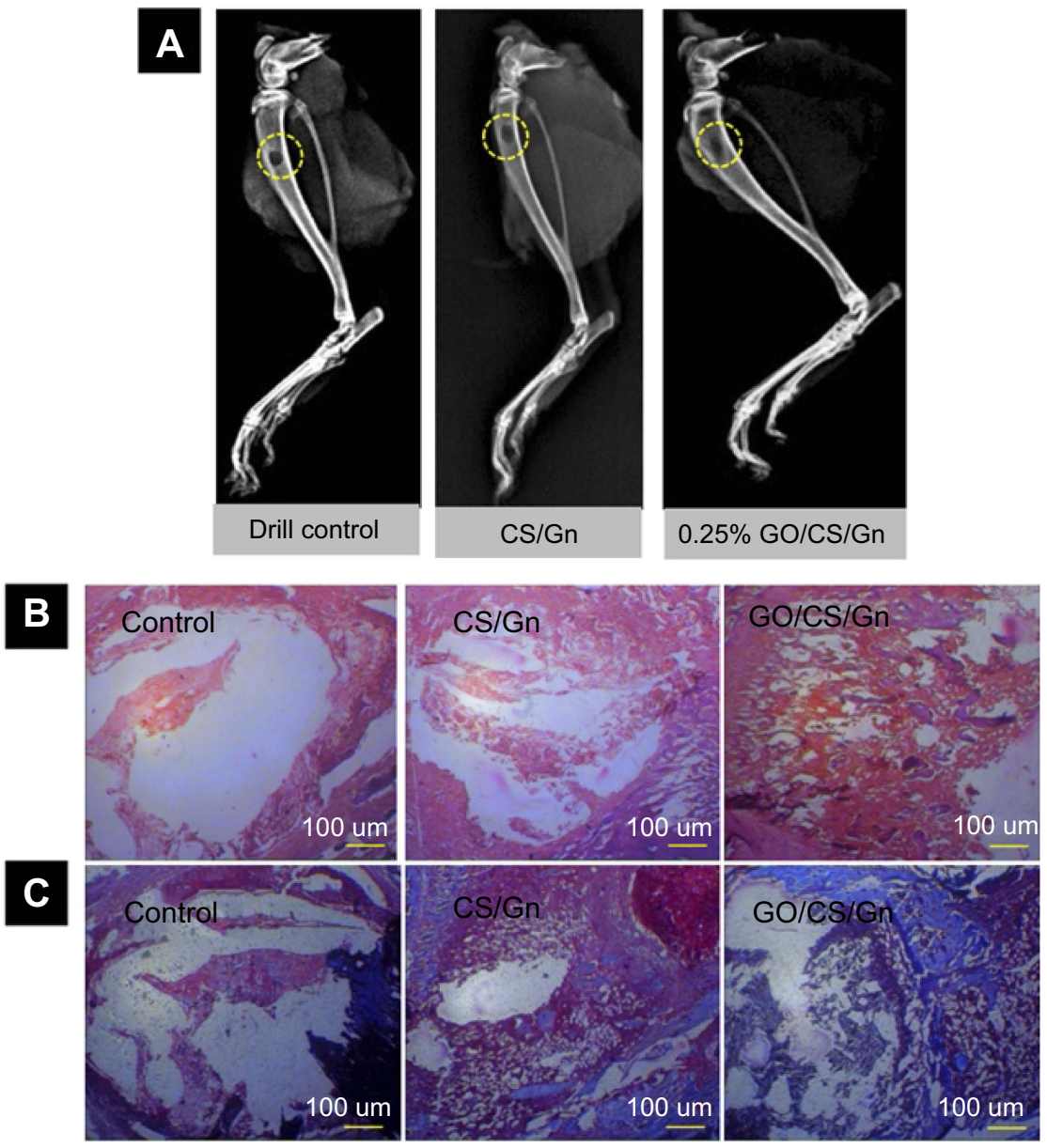

Figure 8 Healing images of rat tibial bone defects in vivo. (A) Representative X-ray photographs of bone defects of control clot (no filler), filled with GO/GN and filled with GO/CS/GN scaffolds after 2 weeks of implantation. (B) H\&E staining and (C) Masson's trichrome staining of rat tibial bone sections after 2 weeks of post-implantation. The scale bar is $100 \mu \mathrm{m}$.

Notes: Reprinted from Saravanan S, Anjali C, Vairamani M, Sastry T, Subramanian K, Selvamurugan N. Scaffolds containing chitosan, gelatin and graphene oxide for bone tissue regeneration in vitro and in vivo. Int J Biol Macromol. 2017;104:1975-1985. Copyright 2017, with permission from Elsevier. ${ }^{199}$

improved viability and proliferation with a suitable $3 \mathrm{D}$ microenvironment. This 3D hydrogel scaffold possesses tunable mechanical strength and enhanced electrical properties due to the presence of GO. Additionally, GO incorporation ensured the creation of complex artificial tissues with mechanical stability and improved cellular performance. This type of 3D scaffolds could be tuned to create different tissue constructs such as blood vessels, skin, skeletal muscle, and connective tissue by providing appropriate microenvironment. ${ }^{204}$

A bioactive $3 \mathrm{D}$ scaffold was prepared by using RGO in combination with porcine acellular dermal matrix (PADM), composed of type I collagen. This porous, biodegradable, conductive, and biocompatible PADM-RGO scaffold was utilized for the nerve tissue engineering. Incorporation of RGO induced mechanical and electrical properties to the scaffold as well as improved the cell-cell interactions. Neural cells are electro-active in nature and thus a bioelectronics interface like RGO can influence the cell behavior. RGO can support the charge transport demand of the cells for regulating the nerve cell characteristics by acting as an interface material. Being electro-active, PADM-RGO scaffold could stimulate the differentiation of MSCs into neural cells and promote faster maturation of the neural cells. MSCs isolated from the femurs and tibias of 4 weeks-old male Wistar rats were introduced into the $3 \mathrm{D}$ scaffold to investigate the neural differentiation process. MSCs were cultured with neural differentiation medium and growth factors to induce the differentiation. Cell viability, structural changes, and protein expression were then analyzed to evaluate the development of neural tissue. Good proliferation and neural differentiation state with upregulation of Nestin, Tuj1, 


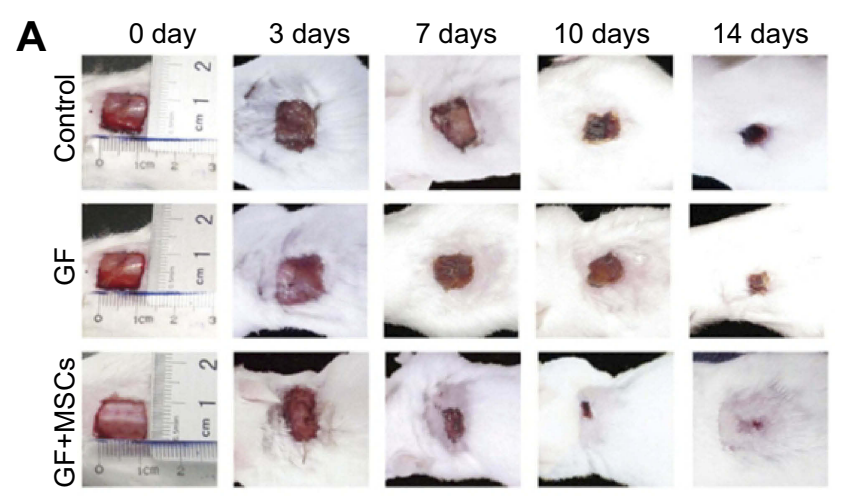

B

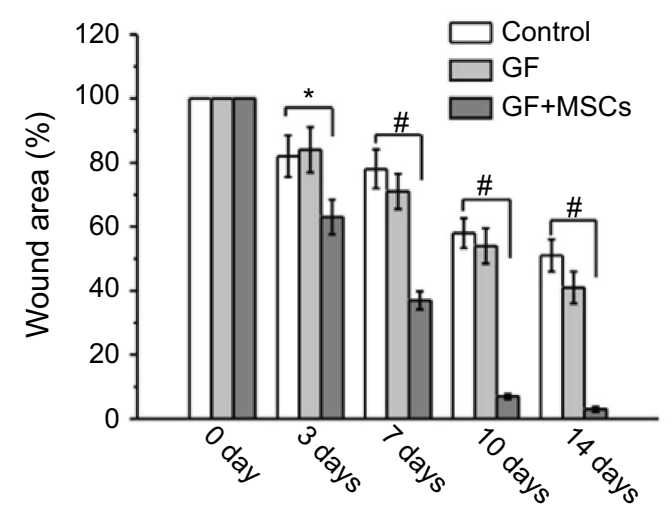

Figure 9 Evaluation of the wound healing effect of GF and GF + MSCs in the in vivo models. (A) Images of the different wound post-transplantation of 3, 7, 10, and 14 days. (B) Graph of wound area (\%) in the experimental groups with the implantation time. Data were presented by means \pm SEM. ${ }^{*} p<0.05$ and ${ }^{\#} p<0.0$ I.

Notes: Reprinted from Li Z, Wang H, Yang B, Sun Y, Huo R. Three-dimensional graphene foams loaded with bone marrow derived mesenchymal stem cells promote skin wound healing with reduced scarring. Mater Sci Eng C. 2015;57:18I-188. Copyright 2015, with permission from Elsevier. ${ }^{203}$

and MAP2 proteins were observed in the cultured cells. The $3 \mathrm{D}$ structure supports the growth and migration of the cells to the inner pores on the scaffold. As compared to 3D PADM alone, the RGO-PADM was found to be more active in promoting neurite sprouting and outgrowth in duration of 7 days. Moreover, the excellent biocompatibility, controlled biodegradability, and conductivity support the use of this scaffold in neural tissue engineering. ${ }^{205}$

RGO-based porous 3D scaffold was used for the regeneration of injured rat spinal cord with mechanical compatibility, biocompatibility, topographical, and biological guidance cues. Exploiting the nontoxic nature of RGO, signs of healing response were observed in the lesion, which encourages the use of RGO scaffold for the repair of the nervous system. ${ }^{206}$ Another 3D scaffold for nerve tissue engineering is developed by Jiang et al, ${ }^{207}$ utilizing GF Murine microglia cell lines (BV2 cells) which were used to induce differentiation of stem cells to nerve cells. Neural stem cells (NSCs) were collected from hippocampus from 1-day postnatal ICR mice which were tested on 2D and 3D scaffolds made of GF. An enhanced neurosphere formation, activation of microglia, and migration of cells were observed in 3D-GF scaffold compared to the 2D-GF possibly due to topographical features of 3D-GF. Moreover, 3D-GF scaffold induced the production of protective factors, such as SDF- $1 \alpha$ to enable NSC migration and adhesion during migration. ${ }^{207}$ In another investigation, chronic tissue response of an injured rat spinal cord toward 3D graphene scaffold was analyzed by López-Dolado et al, ${ }^{208}$ for a duration of 30 days. The RGO scaffolds were prepared by ice segregation-induced self-assembly technique.

Investigations on the adult male Wistar rats with RGO scaffold displayed injury stabilization, filling and healing without scars as shown in Figure 10. In addition, the interface had $\mathrm{GFAP}^{+}$cells and pro-regenerative macrophages. RGO scaffolds induced angiogenesis around and inside the scaffold with numerous new functional blood vessels and regenerated neuronal axons. Whereas, the wound areas without RGO scaffold had few blood vessels and no axons. This investigation proved the capability of graphene-based materials to mediate the establishment of a pro-regenerative scenario in the injured spinal cord, even in the absence of any cells or neural growth factors. This strongly supports the utilization of graphene-based scaffolds in the regenerative therapy. ${ }^{208}$

Another interesting investigation by Guo et al, ${ }^{209}$ resulted in creating a self-powered electrical stimulationassisted neural differentiation system for MSCs. This involves the combination of a triboelectric nanogenerator (TENG) for providing pulsed electric simulation signals and a poly(3,4-ethylenedioxythiophene) (PEDOT) and RGO hybrid microfiber as a 3D scaffold. MSCs cultured on this conductive scaffold possess enhanced proliferation ability and thus improved neural differentiation. Hence, it shows the potential of this self-powered TENG electrical stimulation system for the acceleration of MSC differentiation into neural cells without bio/chemical cues. This encourages the development of graphene scaffold system as a wearable stimulation setup, to assist nerve regeneration for patients through TENG by triggering electrical signals utilizing the mechanical force generated when the patient walks. $^{209}$

\section{Graphene scaffolds in stem cells}

Stem cells are effective tools in regenerative medicine, which could differentiate into various phenotypes. Stem cells could be harvested from a variety of tissues, 


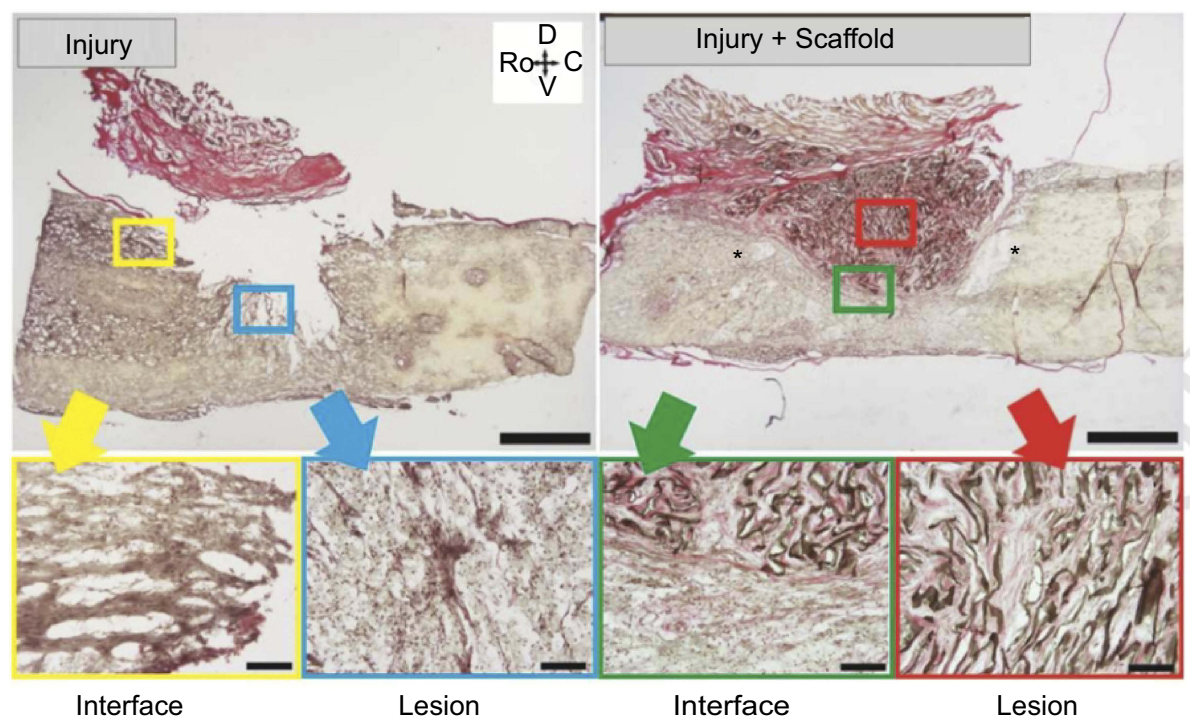

Figure 10 Histological examination images of the injury sites at 30 days post-injury by HvG staining. Spinal cords orientation indicated by the set of arrows: Ro - Rostral, $C-$ Caudal, $D$ - Dorsal, and V - Ventral.

Notes: Reprinted from López-Dolado E, González-Mayorga A, Gutiérrez MC, Serrano MC. Immunomodulatory and angiogenic responses induced by graphene oxide scaffolds in chronic spinal hemisected rats. Biomaterials. 2016;99:72-81. Copyright 2016, with permission from Elsevier. ${ }^{208}$

including bone marrow, adipose, skeletal muscle, and placenta. Based on the type of stem cells (pluripotent or multipotent), they can differentiate into the same lineage cells or different lineage cells. The differentiation process of stem cells varies based on the scaffold components, soluble growth factors, physiological conditions, external stimuli, etc. ${ }^{210}$ Differentiation response to different stimuli and thus the availability of proper scaffolds and toxicity concerns of scaffold materials were the critical factors which limit the stem cell-based tissue engineering. The introduction of graphene 3D scaffolds with excellent biocompatibility, flexibility, mechanical stability, optical transparency, and electrical/thermal conductivity demonstrated a major transformation in stem cell-based tissue engineering by encouraging stem cell adhesion, growth, expansion, and differentiation. ${ }^{106,211-213}$

An investigation on MSCs was carried out by Gui et al, ${ }^{209}$ utilizing an electrically conductive scaffold prepared using RGO and PEDOT hybrid microfiber. The mechanically stable and biocompatible 2D scaffold prepared through this technique utilized a self-powered electrical stimulation system for differentiating MSCs into neural tissue even without any bio/chemical cues. ${ }^{209}$ Similarly, electrically conductive 3D scaffolds were prepared by Sayyar et al, ${ }^{214}$ by utilizing graphene/poly(trimethylene carbonate) composites which are UV-cross linkable. The incorporation of graphene at various concentrations improved the tensile strength, stability, and the electrical conductivity of the scaffold.
Mesenchymal cells (multipotent) derived from adipose tissue were used in the investigation to analyze the cell attachment, viability, proliferation, and differentiation. The presence of graphene in the scaffold had no toxic effects on the viability of MSCs. Moreover, the electrical stimulation of MSCs leads to upregulation of osteogenic markers in terms of ALP activity and Col 1 gene expression, which indicates a promising future of this scaffold in bone tissue engineering. ${ }^{214}$ Electrically conductive GO foams (GOF) were used for the directional growth of neural cells by the differentiation of human neural stem cells (hNSCs) by electrical stimulation. The rolled GOF created a rough surface with high hydrophilicity and numerous pores. The differentiation process of hNSCs into neurons with elongated morphology was observed 2 weeks after the removal of growth factors from the media with electrical stimulations. The electrical resistance of GOF was suitably matched with the electrical stimulation currents $(\sim 20 \mathrm{~mA})$ produced, which induced the differentiation of neural cells. Additionally, the electrical stimulation resulted in accelerated growth and differentiation and proliferation of hNSCs. ${ }^{215}$ Similarly, Li et al, ${ }^{120}$ used GF for NSC culture. The GF exhibited complex structures with interconnected pores and found to be actively encouraging cell growth along with upregulating $\mathrm{Ki}-67$ protein expression. The tested NSC showed fast attachment and excellent networking in the 3D scaffold. With a high specific surface area of $300-800 \mathrm{~m}^{2} / \mathrm{g}$, GF contributed enhanced space for cell attachment and growth. Furthermore, the macroporous 
structure of 3D-GFs permits efficient mass transport of nutrients according to the metabolic requirements of NSC which in turn facilitate cell proliferation. Compared to 2D graphene, 3D GFs showed better performance in the cellular communication, transportation of oxygen and nutrients, removal of wastes, and cellular metabolism. Moreover, 3D-GFs acted as the perfect system to provide electrical stimulation to NSCs for differentiation. ${ }^{120}$

\section{Scope of 3D graphene scaffolds for liver tissue engineering}

Being the largest internal organ in the human body, liver performs numerous complex functions such as metabolic, synthetic, immunologic, and detoxification processes. Furthermore, liver exhibits a unique capacity for regeneration, like complete restoration of liver mass and function even after a massive damage where at least 33\% of the cells remain intact. However, the ultimate treatment for end-stage chronic liver ailments is liver transplantation, which is limited by the shortage of donors. Cell-based treatments could be a promising alternative to organ transplantation. Regardless of the complex structure and function of the liver, the advances in cell and tissue engineering, stem cell therapy, reprogramming, and engineered biomaterials have accelerated the progress of liver tissue engineering. ${ }^{216-220}$ The main parenchymal cells are liver hepatocytes. The ultimate challenge of cell-based liver therapeutic strategy is the tendency of hepatocytes to fail in performing the liver-specific functions and loss of replication capacity when isolated from the normal in vivo microenvironment. Moreover, another critical factor is the presence of microenvironmental signals - soluble factors, ECM components, and heterotypic cell-cell interactions, which are to be maintained in the regulation of hepatocyte survival and phenotypic stability. ${ }^{220}$

Various approaches have been developed to prevent the functional deterioration of hepatocytes such as a suitable ECM and co-culturing with non-parenchymal cells of liver. Moreover, differentiation of human stem cells to hepatocytes is also used for liver tissue engineering applications. ${ }^{221}$ Numerous biomaterials and polymer scaffolds are utilized in liver tissue engineering. ${ }^{222}$ Hepatic tissue engineering encompasses several approaches to develop adjunct internal liver support methods, such as hepatocyte transplantation and implantable hepatocytebased devices, as well as temporary extracorporeal liver support techniques, such as bioartificial liver assist devices. $^{223}$

For the large vital organs such as the liver, kidney, and heart, vascularization is critical to provide permanent engraftment and mass transfer of oxygen and nutrients. To form a 3D construct to generate a complete vascular system to be integrated with engineered tissue, micromachining technologies on silicon and Pyrex surfaces were carried out with standard photolithography techniques. The branched architecture of vascular and capillary networks was etched onto silicon and Pyrex surfaces, where hepatocytes and endothelial cells were cultured and subsequently lifted as single-cell monolayers from these 2D molds. During the investigations, the cells were found to be viable and proliferative on these surfaces. Moreover, hepatocytes maintained functions like albumin productionand the monolayers were folded into 3D tissues. This microfabrication technique found to be useful to form $3 \mathrm{D}$ conformations of living vascularized tissue for implantation. $^{224} \mathrm{~A}$ major limitation in the construction of a functional engineered liver is the short-term survival and rapid de-differentiation of hepatocytes in culture. However, the $3 \mathrm{~T} 3$ fibroblast cells in a co-culture system displayed the potential to modulate function and viability of hepatocytes. Over an 18-day period after isolation, hepatocytes in pure culture rapidly declined in viability, lost two function markers, which is the secretion of albumin and ethoxyresorufin O-dealkylase activity. But the co-cultured hepatocytes maintained viability, possessed well-formed canalicular systems and displayed both functional markers. ${ }^{225}$

Tissue engineering with 3D porous biomaterials is used for developing hepatic tissue, where cell seeding and distribution are carried out in an alginate scaffold. The structure and interconnectivity and hydrophilic nature of the alginate scaffold enabled efficient seeding of hepatocytes into the scaffolds up to $90 \%$ of the initial cells. Centrifugal force utilized seeding enhanced cell distribution in the scaffolds with higher viability and formed a network of connecting spheroids. In the resulted high-density cellular constructs, hepatocellular functions such as albumin and urea secretion as well as detoxification remained high during the 7-day culture. ${ }^{226}$ The construction of a functional liver-tissue equivalent using tissue engineering is a complex task because it requires high-density blood vessel network, where decellularization technology is the solution to this problem. Triton $\mathrm{X}-100$ is used to obtain a 
decellularized liver tissue with a fine vascular tree network template, where the distance between each vascular structure was less than $1 \mathrm{~mm}$. HUVECs and hepatocytes/spheroids were introduced to the structure to prove that decellularized liver tissue is a potential scaffold for creating a practical liver tissue using tissue engineering technology. $^{227}$

A geometrically polarized scaffold structure for a bioartificial liver support system was developed by using polyethylenterephthalate fabric with one of its side coated with a biodegradable PLGA film. The structure ensures the stability of the membrane during degradation. Upon hepatocyte culture, depending on the mesh size and on the pretreatment, aggregates were formed in the scaffold. The largest aggregates could be observed after 48 hrs when PVLA coating, large mesh size, and EGF were combined. $^{228}$ To engineer a uniformly continuous sheet of hepatic tissue using isolated primary hepatocytes, a temperature-responsive surface was used for efficient engraftment. When cultured on the temperature-responsive surface, it resulted in good engraftment to the surrounding cells, with the formation of $2 \mathrm{D}$ hepatic tissues that stably persisted for longer than 200 days. $^{229}$ However, the bioartificial liver device requires a suitable ECM for hepatocyte culture because hepatocytes are anchorage-dependent cells and are highly sensitive. Galactose-carrying synthetic ECMs derived from synthetic polymers and natural polymers were found to bind to hepatocytes through a receptormediated mechanism, resulting in enhanced hepatocyte functions. $^{230}$

In another study, a decellularized porcine, a liverderived biomatrix acts as a bioresorbable scaffold for primary rat hepatocytes. In the liver-derived biomatrix, hepatocytes were maintained for up to 45 days and liverspecific functions such as albumin synthesis, urea production, and P-450 IA1 activity were found to be significantly improved. In addition, this liver-derived biomatrix was found to be a bioresorbable and can be easily manipulated as an in vitro scaffold material. ${ }^{231}$ In a more recent report, a highly porous $\mathrm{CS}$-gelatin hybrid scaffold for liver tissue engineering was prepared by combining rapid prototyping, microreplication, and freeze-drying techniques. The scaffolds possess analogous configurations of veins, flowchannel network, and hepatic chambers. It also has excellent hydrophilicity and biodegradability. SEM and histological analyses show that it facilitates hepatocyte growth in the inner layer of the scaffold with the formation of large colonies in the predefined hepatic chambers, where these cavities could completely filled with hepatocytes during the 7-day culture. Albumin secretion and urea synthesis further indicated that the well-organized scaffolds were suitable for hepatocyte culture. ${ }^{232}$ Using rapid prototyping technology, 3D structures composed of hepatocytes and gelatin hydrogel have been produced. An accurate 3D micropositioning system with a pressure-controlled syringe was employed to deposit cell/biomaterial structures with a lateral resolution of $10 \mu \mathrm{m}$. The pressure-activated micro-syringe creates a wide variety of $3 \mathrm{D}$ patterns with different arrays of channels. More than 30 layers of hepatocyte/gelatin mixture were laminated into a high spatial structure which remained viable and performed biological functions in the construct for more than 2 months. The rapid prototyping technology supports the high-throughput production of artificial human tissues or organs. ${ }^{233}$

Primary rat hepatocytes and HepG2 cells were seeded on CS-Col hydrogel-coated textile scaffolds where, pure Col and Col blended scaffolds allowed higher cell growth compared to pure CS scaffold. It was suggested that hydrogel-coated textile scaffolds allowed favorable hepatocyte attachment, spheroid formation, and maintenance of function. These scaffolds could be useful for co-culturing hepatocytes and nonparenchymal endothelial cells in bioartificial liver support systems. ${ }^{234}$

Poly(3-hydroxybutyrate-co-3-hydroxyvalerate) microspheres were utilized to evaluate the synergistic effects of ECM protein combinations (Col-type I, laminin, and fibronectin) on a human hepatoma cell line, Hep3B to evaluate its proliferation and functions. The in vitro culture of Hep3B with ECM proteins-modified microspheres for 2 weeks was assessed by two hepatic functions, albumin secretion and P-450 activity via ELISA and EROD assays. The results showed that the combination of ECM proteins on microsphere surfaces has a significant effect on the proliferation of Hep3B cells, thus better at mimicking the in vivo environment for liver tissue engineering. ${ }^{235}$ To investigate the biocompatibility and degradation of composite silk fibroin/gelatin scaffolds, in vivo analysis was done on Sprague-Dawley rats. A substantial cell attachment and proliferation were observed on the 2D scaffolds. Based on the gelatin concentration, it was observed that the cell adhesion and scaffold degradation rate have also improved. Despite slight inflammation, the human hepatic QZG cells showed excellent proliferation and relative growth rate on the $2 \mathrm{D}$ scaffolds. ${ }^{236}$

Creating a transplantable liver tissue construct requires expansion of cells in an in vitro phase; genetic or 
immunological manipulation of cells; cryopreservation; and ex vivo genetic modification of patient's own cells prior to transplantation. Function and differentiation of liver cells are influenced by the 3D organ architecture. The use of polymeric scaffold permits 3D formation of a tissue and specific stimulations essential for appropriate differentiation of transplanted cells. In addition, culturing hepatocytes permits culture in a flow bioreactor system with increased function and survival of the cultured cells. Based on bioreactor technology, bioartificial liver devices were developed for extracorporeal liver support. ${ }^{237}$ Bioreactors have supported in hepatocyte survival and maintain viable cells for several weeks. Incorporating concepts such as MicroElectroMechanical systems technology to bioreactors could promise the development of a fully functioning and implantable livers in the near future. ${ }^{238}$

In vitro and in vivo investigations on the feasibility of selective propagation and differentiation of hepatocyte progenitors on poly-L-lactic acid (PLLA) 3D scaffolds were evaluated in the presence of nicotinamide, dimethyl sulfoxide, and oncostatin M. Albumin and DNA production in PLLA-cultured fetal mouse liver cells improved with culture time. Moreover, grafting of this in vitro PLLA-engineered liver tissue construct into the peritoneal cavity of $70 \%$ hepatectomized mice displayed a remarkably higher presence of albumin positive engrafted cells within 15 days after the operation. ${ }^{239}$ In another study, a microfabricated array bioreactor was made of 3D silicon wafer scaffolds with cell-adhesive walls by deep reactive ion etching. A cell-retaining filter and reactor housing were designed to deliver a continuous perfusate through the $3 \mathrm{D}$ tissue mass. When primary rat hepatocytes were seeded into the reactors and cultured for up to 2 weeks, cells were rearranged extensively to form tissue-like structures and remained viable throughout the culture period. Furthermore, the preaggregation of the cells into spheroidal structures prior to seeding has improved the morphogenesis of tissue structure and upkeep of viability. ${ }^{240}$ To evaluate the success of grafting rat and sheep decellularized liver matrix (DLM) into the normal rat liver, natural cell seeding process in homo/xenograft of DLM was compared. To compare the efficacy, biopsies of homograft and xenograft were assessed 8 weeks postoperatively, with histological evaluation and enzymatic assays for both in vivo and in vitro recellularized samples. In vitro recellularized DLMs were more analogous to natural ones compared with in vivo recellularized livers. Nevertheless, homografts displayed a more organized structure compared with xenografts. ${ }^{241}$ When hepatocytes were cocultured with nonparenchymal cells from Lewis rats, they successfully attached and survived with functions on the 3D polymer (copolymers of polylactide-co-glycolide) microporous scaffolds in both static and flow conditions. ${ }^{242}$ Besides this, the development of cellularbased liver tissue engineering is also focused on treating some genetic liver diseases such as Criglar-Najjar syndrome and glycogen storage-related diseases. The treatment was carried out by utilizing an agonistic antibody that stimulates the HGF/cMet pathway to achieve persistent survival of human hepatocytes ( $>140$ days), which was grafted into mice under the kidney capsule space. ${ }^{243}$ The safety profile of new drugs was then assessed based on the drug-liver interactions via in vitro screens based on cultured hepatocytes. In short, the complex liver physiology through the incorporation of heterotypic cell-cell interactions, 3D architecture, and perfused flow, could improve the safety profile analysis in drug discovery and development, including applications in molecular therapeutics. $^{244}$

Ultimately, the definitive goal of liver tissue engineering is creating an entirely functional transplantable liver in vitro. For this, adult hepatocytes or stem cell-derived hepatocytelike cells (HLCs) were engineered and maintained in an ECM like 3D structure to maintain their functional phenotype. ${ }^{245}$ HLCs are useful in individualized drug development, toxicity testing, and disease modeling. ${ }^{246}$ However, the limited growth and differentiation potential of adult hepatocytes were of concern in liver tissue engineering. On the other hand, foetal liver cellspossess an enormous growth and differentiation potential, hence, could be utilized for regenerative therapy. ${ }^{247}$ In liver tissue engineering, a 3D scaffold can be incorporated with hepatocytes, which are embedded in hydrogels or pre-seeded in the biomaterial scaffolds, like 3D bioprinting, where hepatocytes are mixed with a bio-ink and the mixture is printed in different forms, such as tissue-like layers or spheroids. ${ }^{248-250}$ During the last decade, the struggles to develop a native ECM mimicking cell microenvironment of liver tissue have achieved some milestones, which resulted into forms of bioreactors, perfusion equipment, and cell expansion systems, etc. The future implantable liver therapy aims at cell encapsulation, 3D printing, and decellularization-recellularization technologies. Possibility of inflammatory responses is the expected challenges of the cell encapsulation techniques. The in vivo investigation of human HLCs derived from induced pluripotent stem cells (iPSC) encapsulated in alginate beads along 
with human hepatic stellate cells exhibited hepatic differentiation and excellent immunocompetency in mice models without causing immune rejection for up to 24 days. ${ }^{251}$ In the case of $3 \mathrm{D}$ printed liver tissues, the cytocompatibility of the printing medium, extrusion pressure, thickness of the construct, temperature changes are few factors limiting the culturing of hepatocytes. ${ }^{252,253}$ When tested, the mouse iPSC derived hepatocytes mixed with alginate hydrogels displayed increased metabolic functions up to 28 days as in vitro culture and maintained biological functions of liver tissue up to transplantation in animal models. ${ }^{254}$ 3D scaffolds from artificial and natural sources were also utilized for hepatic tissue culture. ${ }^{255}$ Decellularized tissues and organs resulted in perfusable ECM-derived scaffolds with preserved vascular integrity and natural tissue complexity for tissue engineering and drug toxicity testing. ${ }^{256,257}$ The implantable liver tissue engineering construct has constraints of biocompatibility, biodegradability, absence of fibrotic reaction, and maintenance of metabolic function. Similarly, the whole organ engineering in liver requires thrombogenic reactions, immunogenic functions, and long-term metabolic functions.

In spite of the various advancements in liver tissue engineering using biomaterials, however, there are very limited studies utilizing graphene nanomaterials. The concerns about cytotoxicity, degradation, clearance from body, and inflammatory responses of graphene materials in hepatic tissue were the limiting factors and hindrance for further development. ${ }^{258-261}$ Interestingly, some graphene derivatives, with specific preparation methods for biocompatibility, are excellent biomaterials as 3D scaffolds for liver. Investigations of graphene nanomaterials like GO and GQD on hepatocytes showed their biocompatibility and nontoxic nature. ${ }^{262,263}$ In order to analyze the biocompatibility and degradation kinetics on liver cells, HepG2 hepatocarcinoma cells were seeded on 3D graphene scaffold. Analysis of this scaffold showed high cell viability $(>90 \%)$, low lactate production, exceptional oxygenation platform, and a two-step oxidative biodegradation. These aspects emphasize the prospect of fabricating a fruitful 3D platform for the regeneration of liver tissue. $^{264}$ Characteristics such as excellent biocompatibility, specific surface area, interaction with cells (to promote cell growth, proliferation, and differentiation), electrical conductivity, and high porosity within the continuous macroporous structure enable efficient mass transfer (easy transport of nutrients, metabolites, waste products) and cell-cell interactions. Moreover, an influence on the stem cell differentiation, biodegradation, wettability, and anti-inflammatory properties supports the use of graphene-based materials as an excellent scaffold material for the future hepatic tissue engineering. In contrast, investigations of GO on male albino mice showed time and dose-dependent hepatotoxicity, oxidative stress, kupffer cell activation, DNA fragmentation, genotoxicity, etc. ${ }^{265}$ Similarly, introduction of GO in Sprague-Dawley rats exhibited oxidative stress associated toxicity. The biochemical and histopathological analysis reported serum biochemical changes, escalation in the level of ROS, liver enzymes (alanine, aspartate, alkaline phosphates), concentration of lipid hydroperoxide and damage to liver tissue. ${ }^{265}$ Advances in stem cell-based therapies, liver-on-a-chip technologies, disease modeling, drug testing, and organ-specific vascularization technique offer promise to the liver regenerative therapy. ${ }^{266-268}$ In addition, optimization of graphene-based compatible 3D scaffolds along with stem cell sources and bioengineering approaches could deliver a fully functional transplantable liver for the future generations.

\section{Limitations of graphene nanocomposite based 3D scaffold}

The major concern of graphene-based 3D scaffold is its toxicity. Though many investigations have been successfully proved the biocompatible nature of graphene-based scaffolds, few investigations point out the possibility of cytotoxicity of graphene materials. ${ }^{269}$ Numerous functionalization methods are available to alleviate the cytotoxic response of graphene nanomaterials. Hitherto, based on the structure, size and preparation methods, toxicity could be varied. ${ }^{185,270,271}$ Another concern is the mass transfer in the scaffold for the proper access of nutrients to cells and removal of waste metabolites. However, the macroporous 3D scaffolds made of GF found to be efficient in mass transfer aspects and efficient oxygenation in tissue engineering. By altering the pore size or pore distribution of the scaffold, mass transfer and oxygenation of the scaffold could be improved. Other issues faced in 3D graphene scaffold are biodegradation kinetics of graphene. The biodegradation kinetics of the scaffold is critical as the degradation kinetics of scaffold material should match with the cell proliferation and construct formation. Delayed or fast degradation kinetics of the scaffold could negatively influence and collapse the engineered tissue construct. Due to the 3D complex structure, the visualization of cell proliferation and vascularization is also 
limited. However, the interconnectivity of the pores in the 3D scaffold enables cell signaling, encourages growth, proliferation, and tissue formation in 3D tissue engineering. In case of bioprinting, solid free form of fabrication of scaffold and introduction of an artificial vascularization system could also be presented to achieve a sophisticated scaffold design. ${ }^{166,272}$

\section{Conclusions}

The utilization of graphene-based materials in 3D scaffolds creating a revolutionary impact on the tissue engineering field by providing biocompatible and biomimicking scaffolds. The 3D scaffolds made of graphene with nanotopography recreate the real ECM conditions owing to their structural, chemical and biological responses. The micro/macroporous structure promotes cell-cell interactions, proper signaling, enhanced oxygenation, and improved cellular adhesion/proliferation. The different physiochemical properties of graphene nanomaterials permit a favorable microenvironment for the enhanced growth of cells and thus provide required stimuli for cellular differentiation to specific cell lineage. The 3D scaffolds made of graphene-based materials enable selective permeability to gases, improved oxygenation to entire scaffold along with proper mass transfer which enables the transport of nutrients and waste metabolites in the system. Despite the limitations, bioprinting is an excellent alternative for bioactive $3 \mathrm{D}$ scaffold preparation with reliable features such as control over the pore size, repeatability of the scaffold, ability to create proper vascularization which supports efficient mass transfer. Moreover, based on the type of the tissue to be cultured, the hardness of the scaffold and topography could be adjusted during the preparation of scaffold. The biodegradation kinetics, water retention property, and excellent mechanical stability make graphene 3D scaffold a better in vitro system, which closely resembles in vivo conditions. The outstanding electrical conductivity is another excellent feature which qualifies the use of graphene scaffolds for cardiac and neural tissue culture. Response of graphene 3D scaffold toward different physiochemical external cues, to endorse the differentiation of pluri/totipotent stem cells is another attractive feature which is being explored in tissue engineering. However, the anxiety over the toxicity and the exclusion of graphene materials from organisms remain as a serious concern which limits its further applications. An extensive investigation on the in vivo response of graphene materials could reveal the critical factors which induce toxic responses and could extend the possibilities of graphene scaffolds in clinical investigations. Considering the success of graphene-based 3D scaffolds in heart, skin, bone, neuron, and cartilage engineering, it could also be a promising tool in cultivating hepatocytes for liver tissue engineering in the near future.

\section{Acknowledgment}

The authors acknowledge financial support received from the United Arab Emirates University Start-up Research Fund, project number $31 \mathrm{~N} 154$, UAE.

\section{Disclosure}

The authors report no conflicts of interest in this work.

\section{References}

1. Lavik E, Langer R. Tissue engineering: current state and perspectives. Appl Microbiol Biotechnol. 2004;65(1):1-8. doi:10.1007/ s00253-004-1580-z

2. Atala A. Engineering tissues, organs and cells. J Tissue Eng Regen Med. 2007;1(2):83-96. doi:10.1002/term.18

3. Lanza R, Langer R, Vacanti JP. Principles of Tissue Engineering. London: Academic press; 2011.

4. Minuth WW, Sittinger M, Kloth S. Tissue engineering: generation of differentiated artificial tissues for biomedical applications. Cell Tissue Res. 1997;291(1):1-11.

5. Nerem RM, Sambanis A. Tissue engineering: from biology to biological substitutes. Tissue Eng. 1995;1(1):3-13.

6. Mao AS, Mooney DJ. Regenerative medicine: current therapies and future directions. Proc Natl Acad Sci USA. 2015;112(47):1445214459.

7. Atala A. Engineering organs. Curr Opin Biotechnol. 2009;20 (5):575-592.

8. Marx V. Tissue engineering: organs from the lab. Nature. 2015;522 (7556):373-377.

9. Adachi T, Osako Y, Tanaka M, Hojo M, Hollister SJ. Framework for optimal design of porous scaffold microstructure by computational simulation of bone regeneration. Biomaterials. 2006;27 (21):3964-3972.

10. Chen Y, Zhou S, Li Q. Microstructure design of biodegradable scaffold and its effect on tissue regeneration. Biomaterials. 2011;32(22):5003-5014. doi:10.1016/j.biomaterials.2011.03.064

11. Hollister SJ, Maddox R, Taboas JM. Optimal design and fabrication of scaffolds to mimic tissue properties and satisfy biological constraints. Biomaterials. 2002;23(20):4095-4103.

12. Velasco MA, Narváez-Tovar CA, Garzón-Alvarado DA. Design, materials, and mechanobiology of biodegradable scaffolds for bone tissue engineering. Biomed Res Int. 2015;2015:729076.

13. Khoruzhenko A. 2D-and 3D-cell culture. Biopolym Cell. 2011;27 (1):17-24. doi: $10.7124 / \mathrm{bc} .00007 \mathrm{D}$

14. Baharvand H, Hashemi SM, Ashtiani SK, Farrokhi A. Differentiation of human embryonic stem cells into hepatocytes in 2D and 3D culture systems in vitro. Int J Deve Biol. 2004;50 (7):645-652. doi:10.1387/ijdb.052072hb

15. Pampaloni F, Reynaud EG, Stelzer EH. The third dimension bridges the gap between cell culture and live tissue. Nat Rev Mol Cell Biol. 2007;8(10):839-845. doi:10.1038/nrm2236 
16. Ravi M, Paramesh V, Kaviya S, Anuradha E, Solomon F. 3D cell culture systems: advantages and applications. J Cell Physiol. 2015;230(1):16-26. doi:10.1002/jcp.24683

17. Kim JB, Stein R, O'hare MJ. Three-dimensional in vitro tissue culture models of breast cancer - a review. Breast Cancer Res Treat. 2004;85(3):281-291. doi:10.1023/B:BREA.0000025418. $88785.2 \mathrm{~b}$

18. Sun T, Jackson S, Haycock JW, MacNeil S. Culture of skin cells in $3 \mathrm{D}$ rather than $2 \mathrm{D}$ improves their ability to survive exposure to cytotoxic agents. J Biotechnol. 2006;122(3):372-381. doi:10.1016/ j.jbiotec.2005.12.021

19. Breslin S, O'Driscoll L. Three-dimensional cell culture: the missing link in drug discovery. Drug Discov Today. 2013;18(5):240-249. doi:10.1016/j.drudis.2012.10.003

20. Thoma CR, Zimmermann M, Agarkova I, Kelm JM, Krek W. 3D cell culture systems modeling tumor growth determinants in cancer target discovery. Adv Drug Deliv Rev. 2014;69:29-41. doi:10.1016/ j.addr.2014.03.001

21. Hartung T. 3D-A new dimension of in vitro research. Adv Drug Deliv Rev. 2014;69:vi. doi:10.1016/j.addr.2014.04.003

22. Dhandayuthapani B, Yoshida Y, Maekawa T, Kumar DS. Polymeric scaffolds in tissue engineering application: a review. Int J Polym Sci. 2011;2011:290602.

23. Carletti E, Motta A, Migliaresi C. Scaffolds for tissue engineering and 3D cell culture. 3D Cell Cult Methods Protoc. 2011;695:17-39.

24. Wei G, Ma PX. Partially nanofibrous architecture of 3D tissue engineering scaffolds. Biomaterials. 2009;30(32):6426-6434.

25. Mandal BB, Kundu SC. Cell proliferation and migration in silk fibroin 3D scaffolds. Biomaterials. 2009;30(15):2956-2965.

26. Amann A, Zwierzina M, Kern J, et al. Establishment of a multicellular $3 \mathrm{D}$ cell culture model for tumor-endothelial cell interaction. AACR. 2016;76:1-13.

27. Randle DH, Fang Y, Eglen RM. 3D Cell culture and dish based organogenesis: optimizing in vitro cellular physiology. In: Bittker JA, Ross NT, editors. High Throughput Screening Methods. Cambridge: Royal Society of Chemistry; 2016;239-251.

28. Lima PAL, Resende CX, de Almeida Soares GD, Anselme K, Almeida LE. Preparation, characterization and biological test of 3D-scaffolds based on chitosan, fibroin and hydroxyapatite for bone tissue engineering. Mater Sci Eng C. 2013;33(6):3389-3395.

29. Liang M, Yao J, Chen X, Huang L, Shao Z. Silk fibroin immobilization on poly (ethylene terephthalate) films: comparison of two surface modification methods and their effect on mesenchymal stem cells culture. Mater Sci Eng C. 2013;33(3):1409-1416.

30. Kavya K, Jayakumar R, Nair S, Chennazhi KP. Fabrication and characterization of chitosan/gelatin/nSiO 2 composite scaffold for bone tissue engineering. Int J Biol Macromol. 2013;59:255-263.

31. Martins AM, Eng G, Caridade SG, JoF M, Reis RL, VunjakNovakovic G. Electrically conductive chitosan/carbon scaffolds for cardiac tissue engineering. Biomacromolecules. 2014;15 (2):635-643.

32. Ayaz HGŞ, Perets A, Ayaz H, et al. Textile-templated electrospun anisotropic scaffolds for regenerative cardiac tissue engineering. Biomaterials. 2014;35(30):8540-8552.

33. Liu Q, Tian S, Zhao C, et al. Porous nanofibrous poly (L-lactic acid) scaffolds supporting cardiovascular progenitor cells for cardiac tissue engineering. Acta Biomater. 2015;26:105-114.

34. Billiet T, Gevaert E, De Schryver T, Cornelissen M, Dubruel P. The 3D printing of gelatin methacrylamide cell-laden tissue-engineered constructs with high cell viability. Biomaterials. 2014;35(1):49-62.

35. Mihic A, Li J, Miyagi Y, et al. The effect of cyclic stretch on maturation and 3D tissue formation of human embryonic stem cellderived cardiomyocytes. Biomaterials. 2014;35(9):2798-2808.

36. Beaumont M, Kondor A, Plappert S, et al. Surface properties and porosity of highly porous, nanostructured cellulose II particles. Cellulose. 2017;24(1):435-440.
37. Möllers S, Heschel I, Damink LHO, et al. Cytocompatibility of a novel, longitudinally microstructured collagen scaffold intended for nerve tissue repair. Tissue Eng Part A. 2008;15(3):461-472.

38. Ma L, Gao C, Mao Z, et al. Collagen/chitosan porous scaffolds with improved biostability for skin tissue engineering. Biomaterials. 2003;24(26):4833-4841.

39. Bhardwaj N, Sow WT, Devi D, Ng KW, Mandal BB, Cho N-J. Silk fibroin-keratin based 3D scaffolds as a dermal substitute for skin tissue engineering. Integr Biol. 2014;7(1):53-63.

40. Yooyod M, Ross G, Limpeanchob N, Suphrom N, Mahasaranon S, Ross S. Investigation of silk sericin conformational structure for fabrication into porous scaffolds with poly (vinyl alcohol) for skin tissue reconstruction. Eur Polym J. 2016;81:43-52.

41. Yu P, Bao R-Y, Shi X-J, Yang W, Yang M-B. Self-assembled highstrength hydroxyapatite/graphene oxide/chitosan composite hydrogel for bone tissue engineering. Carbohydr Polym. 2017;155:507515 .

42. Simon KA, Mosadegh B, Minn KT, et al. Metabolic response of lung cancer cells to radiation in a paper-based 3D cell culture system. Biomaterials. 2016;95:47-59.

43. van Duinen V, Trietsch SJ, Joore J, Vulto P, Hankemeier T. Microfluidic 3D cell culture: from tools to tissue models. Curr Opin Biotechnol. 2015;35:118-126.

44. Chang C-H, Chen C-H, Liu H-W, et al. Bioengineered periosteal progenitor cell sheets to enhance tendon-bone healing in a bone tunnel. Biomed J. 2012;35(6):473-480.

45. DuRaine GD, Brown WE, Hu JC, Athanasiou KA. Emergence of scaffold-free approaches for tissue engineering musculoskeletal cartilages. Ann Biomed Eng. 2015;43(3):543-554.

46. Liu Y, Luo H, Wang X, et al. In vitro construction of scaffold-free bilayered tissue-engineered skin containing capillary networks. Biomed Res Int. 2013;2013:561410.

47. Masuda S, Shimizu T. Three-dimensional cardiac tissue fabrication based on cell sheet technology. Adv Drug Deliv Rev. 2016;96:103109.

48. Na S, Zhang H, Huang F, et al. Regeneration of dental pulp/dentine complex with a three-dimensional and scaffold-free stem-cell sheet-derived pellet. J Tissue Eng Regen Med. 2016;10(3):261-270.

49. Owaki T, Shimizu T, Yamato M, Okano T. Cell sheet engineering for regenerative medicine: current challenges and strategies. Biotechnol J. 2014;9(7):904-914.

50. See EY-S, Toh SL, Goh JCH. Multilineage potential of bonemarrow-derived mesenchymal stem cell cell sheets: implications for tissue engineering. Tissue Eng Part A. 2010;16(4):1421-1431.

51. Syed-Picard FN, Du Y, Hertsenberg AJ, et al. Scaffold-free tissue engineering of functional corneal stromal tissue. J Tissue Eng Regen Med. 2018;12(1):59-69.

52. Truby RL, Lewis JA. Printing soft matter in three dimensions. Nature. 2016;540(7633):371.

53. Sellaro TL, Ranade A, Faulk DM, et al. Maintenance of human hepatocyte function in vitro by liver-derived extracellular matrix gels. Tissue Eng Part A. 2009;16(3):1075-1082.

54. Frantz C, Stewart KM, Weaver VM. The extracellular matrix at a glance. J Cell Sci. 2010;123(24):4195-4200.

55. Pati F, Jang J, Ha D-H, et al. Printing three-dimensional tissue analogues with decellularized extracellular matrix bioink. Nat Commun. 2014;5:3935.

56. Lock J, Liu H. Nanomaterials enhance osteogenic differentiation of human mesenchymal stem cells similar to a short peptide of BMP7. Int J Nanomedicine. 2011;6:2769-2777.

57. Ovsianikov A, Khademhosseini A, Mironov V. The synergy of scaffold-based and scaffold-free tissue engineering strategies. Trends Biotechnol. 2018;36:348-357.

58. Bettinger CJ, Langer R, Borenstein JT. Engineering substrate topography at the micro-and nanoscale to control cell function. Angew Chem Int Ed. 2009;48(30):5406-5415. 
59. Binulal N, Deepthy M, Selvamurugan N, et al. Role of nanofibrous poly (caprolactone) scaffolds in human mesenchymal stem cell attachment and spreading for in vitro bone tissue engineering - response to osteogenic regulators. Tissue Eng Part A. 2010;16(2):393-404.

60. Cheng K, Kisaalita WS. Exploring cellular adhesion and differentiation in a micro-/nano-hybrid polymer scaffold. Biotechnol Prog. 2010;26(3):838-846.

61. Zhao C, Tan A, Pastorin G, Ho HK. Nanomaterial scaffolds for stem cell proliferation and differentiation in tissue engineering. Biotechnol Adv. 2013;31(5):654-668.

62. Kim J, Choi KS, Kim Y, et al. Bioactive effects of graphene oxide cell culture substratum on structure and function of human adiposederived stem cells. J Biomed Mater Res B Appl Biomater. 2013;101 (12):3520-3530.

63. Rifai A, Pirogova E, Fox K. Encyclopedia of Biomedical Engineering, Volume 1- Biomaterials: Science and Engineering. Narayan RJ, editor. Cambridge: Elsevier, Oliver Walter; 2019.

64. Martinelli V, Bosi S, Peña B, et al. 3D Carbon-nanotube-based composites for cardiac tissue engineering. ACS Appl Biomater. 2018;1(5):1530-1537.

65. Minami K, Kasuya Y, Yamazaki T, et al. Highly ordered 1d fullerene crystals for concurrent control of macroscopic cellular orientation and differentiation toward large-scale tissue engineering. $A d v$ Mater. 2015;27(27):4020-4026.

66. Cheng Q, Rutledge K, Jabbarzadeh E. Carbon nanotube-poly (lactide-co-glycolide) composite scaffolds for bone tissue engineering applications. Ann Biomed Eng. 2013;41(5):904916.

67. Starý V, Bačáková L, Horník J, Chmelík V. Bio-compatibility of the surface layer of pyrolytic graphite. Thin Solid Films. 2003;433 (1):191-198.

68. Bolotin KI, Sikes K, Jiang Z, et al. Ultrahigh electron mobility in suspended graphene. Solid State Commun. 2008;146(9):351-355.

69. Morozov S, Novoselov K, Katsnelson M, et al. Giant intrinsic carrier mobilities in graphene and its bilayer. Phys Rev Lett. 2008;100(1):016602.

70. Lee C, Wei X, Kysar JW, Hone J. Measurement of the elastic properties and intrinsic strength of monolayer graphene. Science. 2008;321(5887):385-388.

71. Balandin AA, Ghosh S, Bao W, et al. Superior thermal conductivity of single-layer graphene. Nano Lett. 2008;8(3):902-907.

72. Cai W, Zhu Y, Li X, Piner RD, Ruoff RS. Large area few-layer graphene/graphite films as transparent thin conducting electrodes. Appl Phys Lett. 2009;95(12):123115.

73. Feng L, Liu Z. Graphene in biomedicine: opportunities and challenges. Nanomedicine. 2011;6(2):317-324.

74. Shen H, Zhang L, Liu M, Zhang Z. Biomedical applications of graphene. Theranostics. 2012;2(3):283-294.

75. Edirisinghe M. The biomedical applications of graphene. $R$ Soc. 2018;8:1-2

76. Terse-Thakoor T, Badhulika S, Mulchandani A. Graphene based biosensors for healthcare. J Mater Res. 2017;32(15):2905-2929.

77. Bai RG, Ninan N, Muthoosamy K, Manickam S. Graphene: a versatile platform for nanotheranostics and tissue engineering. Prog Mater Sci. 2017;91:24-69.

78. Huang X, Yin Z, Wu S, et al. Graphene-based materials: synthesis, characterization, properties, and applications. Small. 2011;7 (14):1876-1902.

79. Muthoosamy K. G Bai R, Manickam S. Graphene and graphene oxide as a docking station for modern drug delivery system. Curr Drug Deliv. 2014;11(6):701-718.

80. Guo S, Dong S. Graphene nanosheet: synthesis, molecular engineering, thin film, hybrids, and energy and analytical applications. Chem Soc Rev. 2011;40(5):2644-2672.

81. Zhang Y, Nayak TR, Hong H, Cai W. Graphene: a versatile nanoplatform for biomedical applications. Nanoscale. 2012;4(13):3833-3842.
82. Abbasi E, Akbarzadeh A, Kouhi M, Milani M. Graphene: synthesis, bio-applications, and properties. Artif Cells Nanomed Biotechnol. 2016;44(1):150-156.

83. Bai RG, Muthoosamy K, Shipton FN, et al. The biogenic synthesis of a reduced graphene oxide-silver (RGO-ag) nanocomposite and its dual applications as an antibacterial agent and cancer biomarker sensor. RSC Adv. 2016;6(43):36576-36587.

84. Chung C, Kim Y-K, Shin D, Ryoo S-R, Hong BH, Min D-H. Biomedical applications of graphene and graphene oxide. Acc Chem Res. 2013;46(10):2211-2224.

85. Dreyer DR, Park S, Bielawski CW, Ruoff RS. The chemistry of graphene oxide. Chem Soc Rev. 2010;39(1):228-240.

86. Pei S, Cheng H-M. The reduction of graphene oxide. Carbon. 2012;50(9):3210-3228.

87. Bai RG, Muthoosamy K, Zhou M, Ashokkumar M, Huang NM, Manickam S. Sonochemical and sustainable synthesis of graphenegold $(\mathrm{G}-\mathrm{Au})$ nanocomposites for enzymeless and selective electrochemical detection of nitric oxide. Biosens Bioelectron. 2017;87:622-629.

88. Thakur S, Karak N. Green reduction of graphene oxide by aqueous phytoextracts. Carbon. 2012;50(14):5331-5339.

89. Veetil JV, Ye K. Tailored carbon nanotubes for tissue engineering applications. Biotechnol Prog. 2009;25(3):709-721.

90. $\mathrm{Ku} \mathrm{SH}$, Lee M, Park CB. Carbon-based nanomaterials for tissue engineering. Adv Healthc Mater. 2013;2(2):244-260.

91. Lin Y, Taylor S, Li H, et al. Advances toward bioapplications of carbon nanotubes. J Mater Chem. 2004;14(4):527-541.

92. Kuila T, Bose S, Mishra AK, Khanra P, Kim NH, Lee JH. Chemical functionalization of graphene and its applications. Prog Mater Sci. 2012;57(7):1061-1105.

93. Liao J, Li Q, Wen J, et al. Graphene nanoparticles-based selfhealing hydrogel in preventing post-operative recurrence of breast cancer. ACS Biomater Sci Eng. 2019;5:768-779.

94. Eswaraiah V, Aravind SSJ, Ramaprabhu S. Top down method for synthesis of highly conducting graphene by exfoliation of graphite oxide using focused solar radiation. J Mater Chem. 2011;21 (19):6800-6803.

95. Chen Y-C, Cao T, Chen C, et al. Molecular bandgap engineering of bottom-up synthesized graphene nanoribbon heterojunctions. Nat Nanotechnol. 2015;10(2):156-160.

96. Jung HS, Choi Y-J, Jeong J, et al. Nanoscale graphene coating on commercially pure titanium for accelerated bone regeneration. RSC Adv. 2016;6(32):26719-26724.

97. Mokkapati V, Tasli NP, Khan Z, et al. NaB integrated graphene oxide membranes for enhanced cell viability and stem cell properties of human adipose stem cells. RSC Adv. 2016;6(61):56159-56165.

98. Akhavan O, Ghaderi E. Flash photo stimulation of human neural stem cells on graphene/ $\mathrm{TiO}_{2}$ heterojunction for differentiation into neurons. Nanoscale. 2013;5(21):10316-10326.

99. Paul A, Hasan A, Kindi HA, et al. Injectable graphene oxide/ hydrogel-based angiogenic gene delivery system for vasculogenesis and cardiac repair. ACS Nano. 2014;8(8):8050-8062.

100. Zhao W, Fang M, Wu F, Wu H, Wang L, Chen G. Preparation of graphene by exfoliation of graphite using wet ball milling. $J$ Mater Chem. 2010;20(28):5817-5819. doi:10.1039/c0jm01354d

101. Chen Z, Ren W, Gao L, Liu B, Pei S, Cheng H-M. Three-dimensional flexible and conductive interconnected graphene networks grown by chemical vapour deposition. Nat Mater. 2011;10(6):424428. doi:10.1038/nmat3001

102. Muthoosamy K, Bai RG, Abubakar IB, et al. Exceedingly biocompatible and thin-layered reduced graphene oxide nanosheets using an eco-friendly mushroom extract strategy. Int $J$ Nanomedicine. 2015;10:1505

103. Qian Y, Song J, Zhao X, et al. Tissue engineering: 3D fabrication with integration molding of a graphene oxide/polycaprolactone nanoscaffold for neurite regeneration and angiogenesis. Adv Sci. 2018;5(4):1870020. doi:10.1002/advs.201870020 
104. Nyambat B, Chen C-H, Wong P-C, Chiang C-W, Satapathy MK, Chuang E-Y. Genipin-crosslinked adipose stem cell derived extracellular matrix-nano graphene oxide composite sponge for skin tissue engineering. $J$ Mater Chem B. 2018;6(6):979-990. doi: $10.1039 / \mathrm{C} 7 \mathrm{~TB} 02480 \mathrm{~K}$

105. Wu D, Samanta A, Srivastava RK, Hakkarainen M. Starch derived nano-graphene oxide paves the way for electrospinnable and bioactive starch scaffolds for bone tissue engineering. Biomacromolecules. 2017;18:1582-1591. doi:10.1021/acs. biomac.7b00195

106. Akhavan O. Graphene scaffolds in progressive nanotechnology/ stem cell-based tissue engineering of the nervous system. J Mater Chem B. 2016;4(19):3169-3190. doi:10.1039/C6TB00152A

107. Jakus AE, Shah R. Multi and mixed 3D-printing of graphenehydroxyapatite hybrid materials for complex tissue engineering. $J$ Biomed Mater Res B Appl Biomater. 2017;105(1):274-283. doi:10.1002/jbm.a.35684

108. Liu Y, Chen T, Du F, et al. Single-layer graphene enhances the osteogenic differentiation of human mesenchymal stem cells in vitro and in vivo. J Biomed Nanotechnol. 2016;12(6):1270-1284.

109. Akhavan O, Ghaderi E, Shirazian SA. Near infrared laser stimulation of human neural stem cells into neurons on graphene nanomesh semiconductors. Colloids Surf $B$ Biointerfaces. 2015;126:313-321. doi:10.1016/j.colsurfb.2014.12.027

110. Jo H, Sim M, Kim S, et al. Electrically conductive graphene/ polyacrylamide hydrogels produced by mild chemical reduction for enhanced myoblast growth and differentiation. Acta Biomater. 2017;48:100-109. doi:10.1016/j.actbio.2016.10.035

111. Liu C, Wong HM, Yeung KWK, Tjong SC. Novel electrospun polylactic acid nanocomposite fiber mats with hybrid graphene oxide and nanohydroxyapatite reinforcements having enhanced biocompatibility. Polymers. 2016;8(8):287. doi:10.3390/ polym 8080287

112. Shin SR, Zihlmann C, Akbari M, et al. Reduced graphene oxide-gelMA hybrid hydrogels as scaffolds for cardiac tissue engineering. Small. 2016;12(27):3677-3689. doi:10.1002/ smll.201600178

113. Mondal MK, Mukherjee S, Saha SK, Chowdhury P, Babu SPS. Design and synthesis of reduced graphene oxide based supramolecular scaffold: a benign microbial resistant network for enzyme immobilization and cell growth. Mater Sci Eng C. 2017;75:11681177. doi:10.1016/j.msec.2017.02.136

114. Holt BD, Arnold AM, Sydlik SA. Peptide-functionalized reduced graphene oxide as a bioactive mechanically robust tissue regeneration scaffold. Polym Int. 2017. doi:10.1002/pi.5375

115. Sacks R, Schein G, Isseroff R, Ricotta V, Simon M, Rafailovich M. The influence of metalized graphene oxide/reduced graphene oxide and sulfonated polystyrene on dental pulp stem cell differentiation and protein adsorption. MRS Adv. 2017;20:1059-1070.

116. Ameri S, Singh P, D'Angelo R, Stoppel W, Black L, Sonkusale S Three dimensional graphene scaffold for cardiac tissue engineering and in-situ electrical recording. Paper presented at: Engineering in medicine and biology society (embc), 2016 IEEE 38th annual international conference of the 2016; Orlando, FL, USA.

117. Lamprecht C, Taale M, Paulowicz I, et al. A tunable scaffold of microtubular graphite for 3D cell growth. ACS Appl Mater Interfaces. 2016;8(24):14980. doi:10.1021/acsami.6b00778

118. Xie H, Chua M, Islam I, et al. CVD-grown monolayer graphene induces osteogenic but not odontoblastic differentiation of dental pulp stem cells. Dent Mater. 2017;33(1):e13-e21. doi:10.1016/j. dental.2016.09.030

119. Golafshan N, Kharaziha M, Fathi M. Tough and conductive hybrid graphene-PVA: alginate fibrous scaffolds for engineering neural construct. Carbon. 2017;111:752-763. doi:10.1016/j. carbon.2016.10.042
120. Li N, Zhang Q, Gao S, et al. Three-dimensional graphene foam as a biocompatible and conductive scaffold for neural stem cells. Sci Rep. 2013;3:1604. doi:10.1038/srep01604

121. Li C, Shi G. Three-dimensional graphene architectures. Nanoscale. 2012;4(18):5549-5563. doi:10.1039/c2nr31467c

122. Bhardwaj N, Chouhan D, Mandal BB. 3D functional scaffolds for skin tissue engineering. In: Deng Y, Jordan Kuiper J, editors. Functional 3D Tissue Engineering Scaffolds. Duxford: Woodhead Publishing, Elsevier; 2018:345-365.

123. Li X, Ye X, Qi J, et al. EGF and curcumin co-encapsulated nanoparticle/hydrogel system as potent skin regeneration agent. Int J Nanomedicine. 2016;11:3993. doi:10.2147/IJN.S104350

124. Kumar S, Chatterjee K. Strontium eluting graphene hybrid nanoparticles augment osteogenesis in a 3D tissue scaffold. Nanoscale. 2015;7(5):2023-2033. doi:10.1039/c4nr05060f

125. Jiang L, Fan Z. Design of advanced porous graphene materials: from graphene nanomesh to 3D architectures. Nanoscale. 2014;6 (4):1922-1945. doi:10.1039/c3nr04555b

126. Kelly CN, Miller AT, Hollister SJ, Guldberg RE, Gall K. Design and structure-function characterization of $3 \mathrm{D}$ printed synthetic porous biomaterials for tissue engineering. Adv Healthc Mater. 2018;7(7):1701095. doi:10.1002/adhm.201701095

127. Trautmann A, Rüth M, Lemke H-D, Walther T, Hellmann R Large 3D direct laser written scaffolds for tissue engineering applications. Paper presented at: Nanophotonics australasia 2017; Melbourne, VIC, Australia; 2017.

128. Feiner R, Fleischer S, Shapira A, Kalish O, Dvir T. Multifunctional degradable electronic scaffolds for cardiac tissue engineering. J Control Release. 2018;281:189-195. doi:10.1016/j.jconrel.2018.05.023

129. Seunarine K, Gadegaard N, Tormen M, Meredith D, Riehle M, Wilkinson C. 3D polymer scaffolds for tissue engineering. Nanomedicine. 2006;1:281-296. doi:10.2217/17435889.1.3.281

130. Hu S, Chen H, Zhou X, et al. Thermally induced self-agglomeration 3D scaffolds with BMP-2-loaded core-shell fibers for enhanced osteogenic differentiation of rat adipose-derived stem cells. Int J Nanomedicine. 2018;13:4145. doi:10.2147/IJN.S177627

131. Mikos AG, Thorsen AJ, Czerwonka LA, et al. Preparation and characterization of poly (L-lactic acid) foams. Polymer. 1994;35 (5):1068-1077. doi:10.1016/0032-3861(94)90953-9

132. Pinto AM, Moreira S, Gonçalves IC, Gama FM, Mendes AM, Magalhães FD. Biocompatibility of poly (lactic acid) with incorporated graphene-based materials. Colloids Surf B Biointerfaces. 2013;104:229-238. doi:10.1016/j.colsurfb.2012.12.006

133. Joshi MK, Pant HR, Tiwari AP, Park CH, Kim CS. Multi-layered macroporous three-dimensional nanofibrous scaffold via a novel gas foaming technique. Chem Eng J. 2015;275:79-88. doi:10.1016/j.cej.2015.03.121

134. Yang G, Su J, Gao J, Hu X, Geng C, Fu Q. Fabrication of wellcontrolled porous foams of graphene oxide modified poly (propylene-carbonate) using supercritical carbon dioxide and its potential tissue engineering applications. J Supercrit Fluids. 2013;73:1-9. doi:10.1016/j.supflu.2012.11.004

135. Jing X, Mi HY, Salick MR, Peng XF, Turng LS. Preparation of thermoplastic polyurethane/graphene oxide composite scaffolds by thermally induced phase separation. Polym Compos. 2014;35 (7):1408-1417. doi:10.1002/pc.22793

136. Sayyar S, Cornock R, Murray E, Beirne S, Officer DL, Wallace GG. Extrusion Printed Graphene/Polycaprolactone/Composites for Tissue Engineering. Materials Science Forum. 2014;773-774:496-502.

137. Kumar S, Azam M, Raj S, et al. 3D scaffold alters cellular response to graphene in a polymer composite for orthopedic applications. $J$ Biomed Mater Res B Appl Biomater. 2015;104:732-749.

138. Zhu J, Marchant RE. Design properties of hydrogel tissue-engineering scaffolds. Expert Rev Med Devices. 2011;8(5):607-626. doi:10.1586/erd.11.27 
139. Yi W, Wu H, Wang H, Du Q. Interconnectivity of macroporous hydrogels prepared via graphene oxide-stabilized pickering high internal phase emulsions. Langmuir. 2016;32(4):982-990. doi:10.1021/acs. langmuir.5b04477

140. Chen Y, Wang Y, Shi X, et al. Hierarchical and reversible assembly of graphene oxide/polyvinyl alcohol hybrid stabilized pickering emulsions and their templating for macroporous composite hydrogels. Carbon. 2017;111:38-47. doi:10.1016/j.carbon.2016.09.059

141. O'Brien FJ, Harley BA, Yannas IV, Gibson L. Influence of freezing rate on pore structure in freeze-dried collagen-GAG scaffolds. Biomaterials. 2004;25(6):1077-1086.

142. Murphy CM, Haugh MG, O'Brien FJ. The effect of mean pore size on cell attachment, proliferation and migration in collagen-glycosaminoglycan scaffolds for bone tissue engineering. Biomaterials. 2010;31 (3):461-466. doi:10.1016/j.biomaterials.2009.09.063

143. Mohandes F, Salavati-Niasari M. Freeze-drying synthesis, characterization and in vitro bioactivity of chitosan/graphene oxide/hydroxyapatite nanocomposite. RSC Adv. 2014;4(49):25993-26001. doi:10.1039/c4ra03534h

144. Unnithan AR, Park CH, Kim CS. Nanoengineered bioactive 3D composite scaffold: a unique combination of graphene oxide and nanotopography for tissue engineering applications. Compos Part B Eng. 2016;90:503-511. doi:10.1016/j.compositesb.2016.01.012

145. Zhang C, Wang L, Zhai T, Wang X, Dan Y, Turng L-S. The surface grafting of graphene oxide with poly (ethylene glycol) as a reinforcement for poly (lactic acid) nanocomposite scaffolds for potential tissue engineering applications. J Mech Behav Biomed Mater. 2016;53:403-413. doi:10.1016/j.jmbbm.2015.08.043

146. Jing X, Mi H-Y, Salick MR, Cordie TM, Peng X-F, Turng L-S. Electrospinning thermoplastic polyurethane/graphene oxide scaffolds for small diameter vascular graft applications. Mater Sci Eng C. 2015;49:40-50. doi:10.1016/j.msec.2014.12.060

147. Murphy SV, Atala A. 3D bioprinting of tissues and organs. Nat Biotechnol. 2014;32(8):773-785. doi:10.1038/nbt.2958

148. Do A-V, Smith R, Acri TM, Geary SM, Salem AK. 3D printing technologies for 3D scaffold engineering. In: Ahmad N, Gopinath P, Dutta R, editors. Functional 3D Tissue Engineering Scaffolds. St. Louis: Elsevier; 2018:203-234.

149. Wang W, Caetano G, Ambler WS, et al. Enhancing the hydrophilicity and cell attachment of 3D printed PCL/graphene scaffolds for bone tissue engineering. Materials. 2016;9(12):992. doi:10.3390/ma9120992

150. Vijayavenkataraman S, Thaharah S, Zhang S, Lu WF, Fuh JYH. 3D-printed $\mathrm{PCL} / \mathrm{rGO}$ conductive scaffolds for peripheral nerve injury repair. Artif Organs. 2018;43:515-523.

151. Geckil H, Xu F, Zhang X, Moon S, Demirci U. Engineering hydrogels as extracellular matrix mimics. Nanomedicine. 2010;5 (3):469-484. doi:10.2217/nnm.10.12

152. Shen H, Lin H, Sun AX, et al. Chondroinductive factor-free chondrogenic differentiation of human mesenchymal stem cells in graphene oxide-incorporated hydrogels. J Mater Chem B. 2018;6 (6):908-917. doi:10.1039/C7TB02172K

153. Saravanan S, Vimalraj S, Anuradha D. Chitosan based thermoresponsive hydrogel containing graphene oxide for bone tissue repair. Biomed Pharmacother. 2018;107:908-917. doi:10.1016/j.biopha.2018.08.072

154. Qian Y, Zhao X, Han Q, Chen W, Li H, Yuan W. An integrated multi-layer 3D-fabrication of PDA/RGD coated graphene loaded PCL nanoscaffold for peripheral nerve restoration. Nat Commun. 2018;9(1):323. doi:10.1038/s41467-017-02598-7

155. Tasnim N, Thakur V, Chattopadhyay M, Joddar B. The efficacy of graphene foams for culturing mesenchymal stem cells and their differentiation into dopaminergic neurons. Stem Cells Int. 2018;2018:3410168.

156. Valencia C, Valencia C, Zuluaga F, Valencia M, Mina J, GrandeTovar C. Synthesis and application of scaffolds of chitosan-graphene oxide by the freeze-drying method for tissue regeneration. Molecules. 2018;23(10):2651. doi:10.3390/molecules23102651
157. Hermenean A, Codreanu A, Herman H, et al. Chitosan-graphene oxide 3D scaffolds as promising tools for bone regeneration in critical-size mouse calvarial defects. Sci Rep. 2017;7(1):16641. doi:10.1038/s41598-017-16599-5

158. Domínguez-Bajo A, González-Mayorga A, López-Dolado E, Serrano MC. Graphene-derived materials interfacing the spinal cord: outstanding in vitro and in vivo findings. Front Syst Neurosci. 2017;11:71. doi:10.3389/fnsys.2017.00071

159. Nguyen AT, Mattiassi S, Loeblein M, et al. Human Rett-derived neuronal progenitor cells in 3D graphene scaffold as an in vitro platform to study the effect of electrical stimulation on neuronal differentiation. Biomedical Mater. 2018;13(3):034111. doi:10.1088/ 1748-605X/aaaf2b

160. Liu P, Chen W, Jia Y, Bai S, Wang Q. Fabrication of poly (vinyl alcohol)/graphene nanocomposite foam based on solid state shearing milling and supercritical fluid technology. Mater Des. 2017;134:121-131. doi:10.1016/j.matdes.2017.08.045

161. Bayer IS. Thermomechanical properties of polylactic acid-graphene composites: a state-of-the-art review for biomedical applications. Materials. 2017;10(7):748. doi:10.3390/ma10070748

162. Han L, Sun H, Tang P, et al. Mussel-inspired graphene oxide nanosheet-enwrapped Ti scaffolds with drug-encapsulated gelatin microspheres for bone regeneration. Biomater Sci. 2018;6(3):538549. doi:10.1039/c7bm01060e

163. Patel A, Xue Y, Hartley R, et al. Hierarchically aligned fibrous hydrogel films through microfluidic self-assembly of graphene and polysaccharides. Biotechnol Bioeng. 2018;115(10):2654-2667. doi:10.1002/bit.26801

164. Girão AF, Semitela Â, Ramalho G, Completo A, Marques PA. Mimicking nature: fabrication of 3D anisotropic electrospun polycaprolactone scaffolds for cartilage tissue engineering applications. Compos Part B-Eng. 2018;154:99-107. doi:10.1016/j. compositesb.2018.08.001

165. Hutmacher DW. Scaffold design and fabrication technologies for engineering tissues - state of the art and future perspectives. J Biomater Sci Polym Ed. 2001;12(1):107-124. doi:10.1163/156856201744489

166. Sachlos E, Czernuszka J. Making tissue engineering scaffolds work. Review: the application of solid freeform fabrication technology to the production of tissue engineering scaffolds. Eur Cell Mater. 2003;5(29):39-40. doi:10.22203/eCM.v005a03

167. Crowder SW, Prasai D, Rath R, et al. Three-dimensional graphene foams promote osteogenic differentiation of human mesenchymal stem cells. Nanoscale. 2013;5(10):4171-4176. doi:10.1039/c3nr00803g

168. Tang M, Song Q, Li N, Jiang Z, Huang R, Cheng G. Enhancement of electrical signaling in neural networks on graphene films. Biomaterials. 2013;34(27):6402-6411. doi:10.1016/j.biomaterials. 2013.05.024

169. Wang Y, Lee WC, Manga KK, et al. Fluorinated graphene for promoting neuro-induction of stem cells. Adv Mater. 2012;24 (31):4285-4290. doi:10.1002/adma.201200846

170. Kazantseva J, Ivanov R, Gasik M, Neuman T, Hussainova I. Graphene-augmented nanofiber scaffolds demonstrate new features in cells behaviour. Sci Rep. 2016;6:1-8.

171. Kalbacova M, Broz A, Kong J, Kalbac M. Graphene substrates promote adherence of human osteoblasts and mesenchymal stromal cells. Carbon. 2010;48(15):4323-4329. doi:10.1016/j.carbon.2010.07.045

172. Mattox DM. Handbook of Physical Vapor Deposition (PVD) Processing. Amsterdam: Elsevier; 2010.

173. Wasalathilake KC, Galpaya DG, Ayoko GA, Yan C. Understanding the structure-property relationships in hydrothermally reduced graphene oxide hydrogels. Carbon. 2018;137:282-290. doi:10.1016/j. carbon.2018.05.036

174. Zhai L, Li L, Zhang Q. Fabrication of capsaicin functionalized reduced graphene oxide and its effect on proliferation and differentiation of osteoblasts. Environ Toxicol Pharmacol. 2018;57:4145. doi:10.1016/j.etap.2017.11.012 
175. Park SY, Park J, Sim SH, et al. Enhanced differentiation of human neural stem cells into neurons on graphene. Adv Mater. 2011;23:36. doi:10.1002/adma.201103379

176. Nayak TR, Andersen H, Makam VS, et al. Graphene for controlled and accelerated osteogenic differentiation of human mesenchymal stem cells. ACS Nano. 2011;5(6):4670-4678. doi:10.1021/ nn200500h

177. Nakayama KH, Hou L, Huang NF. Role of extracellular matrix signaling cues in modulating cell fate commitment for cardiovascular tissue engineering. Adv Healthc Mater. 2014;3(5):628-641. doi:10.1002/adhm.201300620

178. Berg EL, Hsu Y-C, Lee JA. Consideration of the cellular microenvironment: physiologically relevant co-culture systems in drug discovery. Adv Drug Deliv Rev. 2014;69:190-204. doi:10.1016/j. addr.2014.01.013

179. Montanez-Sauri SI, Beebe DJ, Sung KE. Microscale screening systems for 3D cellular microenvironments: platforms, advances, and challenges. Cell Mol Life Sci. 2015;72(2):237-249. doi:10.1007/s00018-014-1738-5

180. Wanjare M, Huang NF. Regulation of the microenvironment for cardiac tissue engineering. Regen Med. 2017;12(2):187-201. doi:10.2217/rme-2016-0132

181. Zlotorynski E. Mechanotransduction: stretching chromatin promotes transcription. Nat Rev Mol Cell Biol. 2016;17(10):610. doi:10.1038/nrm.2016.119

182. Li Z, Lee H, Zhu C. Molecular mechanisms of mechanotransduction in integrin-mediated cell-matrix adhesion. Exp Cell Res. 2016;349(1):85-94. doi:10.1016/j.yexcr.2016.10.001

183. Polacheck WJ, German AE, Mammoto A, Ingber DE, Kamm RD. Mechanotransduction of fluid stresses governs 3D cell migration. Proc Natl Acad Sci USA. 2014;111(7):2447-2452. doi:10.1073/ pnas. 1316848111

184. Baker BM, Chen CS. Deconstructing the third dimension-how 3D culture microenvironments alter cellular cues. J Cell Sci. 2012;125 (13):3015-3024. doi:10.1242/jcs.079509

185. Goenka S, Sant V, Sant S. Graphene-based nanomaterials for drug delivery and tissue engineering. J Control Release. 2014;173:7588. doi:10.1016/j.jconrel.2013.10.017

186. Shin SR, Li Y-C, Jang HL, et al. Graphene-based materials for tissue engineering. Adv Drug Deliv Rev. 2016;105:255-274. doi:10.1016/j.addr.2016.03.007

187. Pinto AM, Gonçalves IC, Magalhães FD. Graphene-based materials biocompatibility: a review. Colloids Surf $B$ Biointerfaces. 2013;111:188-202. doi:10.1016/j.colsurfb.2013.05.022

188. Yang Y, Asiri AM, Tang Z, Du D, Lin Y. Graphene based materials for biomedical applications. Mater Today. 2013;16(10):365-373. doi:10.1016/j.mattod.2013.09.004

189. Ding X, Liu H, Fan Y. Graphene-based materials in regenerative medicine. Adv Healthc Mater. 2015;4(10):1451-1468. doi:10.1002/ adhm.201500203

190. Lee SK, Kim H, Shim BS. Graphene: an emerging material for biological tissue engineering. Carbon Lett. 2013;14(2):63-75. doi:10.5714/CL.2013.14.2.063

191. Zhu W, Qu X, Zhu J, et al. Direct 3D bioprinting of prevascularized tissue constructs with complex microarchitecture. Biomaterials. 2017;124:106-115. doi:10.1016/j.biomaterials.2017.01.042

192. Datta P, Ayan B, Ozbolat IT. Bioprinting for vascular and vascularized tissue biofabrication. Acta Biomater. 2017;51:1-20. doi:10.1016/j.actbio.2017.01.035

193. Zhang X, Zhang Y. Tissue engineering applications of three-dimensional bioprinting. Cell Biochem Biophys. 2015;72(3):777-782. doi:10.1007/s12013-015-0531-x

194. Aphale A, Hitscherich P, Narula R, et al. Biocompatibility of PCLgraphene nanostructured scaffolds with mouse embryonic stem cell-derived cardiomyocytes. Materials. 2015;8:12. doi:10.3390/ ma8125486
195. Shadjou N, Hasanzadeh M. Graphene and its nanostructure derivatives for use in bone tissue engineering: recent advances. J Biomed Mater Res B Appl Biomater. 2016;104:1250-1275. doi:10.1002/ jbm.a.v104.5

196. Gu M, Liu Y, Chen T, et al. Is graphene a promising nano-material for promoting surface modification of implants or scaffold materials in bone tissue engineering? Tissue Eng Part B Rev. 2014;20 (5):477-491. doi:10.1089/ten.teb.2013.0638

197. Nie W, Peng C, Zhou X, et al. Three-dimensional porous scaffold by self-assembly of reduced graphene oxide and nano-hydroxyapatite composites for bone tissue engineering. Carbon. 2017;116:325337. doi:10.1016/j.carbon.2017.02.013

198. Dinescu S, Ionita M, Pandele AM, et al. In vitro cytocompatibility evaluation of chitosan/graphene oxide 3D scaffold composites designed for bone tissue engineering. Biomed Mater Eng. 2014;24 (6):2249-2256. doi:10.3233/BME-141037

199. Saravanan S, Anjali C, Vairamani M, Sastry T, Subramanian K, Selvamurugan N. Scaffolds containing chitosan, gelatin and graphene oxide for bone tissue regeneration in vitro and in vivo. Int $J$ Biol Macromol. 2017;104:1975-1985. doi:10.1016/j. ijbiomac.2017.01.034

200. Liao J, Qu Y, Chu B, Zhang X, Qian Z. Biodegradable CSMA/ PECA/graphene porous hybrid scaffold for cartilage tissue engineering. Sci Rep. 2015;5:9879. doi:10.1038/srep09879

201. Frueh FS, Menger MD, Lindenblatt N, Giovanoli P, Laschke MW. Current and emerging vascularization strategies in skin tissue engineering. Crit Rev Biotechnol. 2016;371-13.

202. Lee EJ, Lee JH, Shin YC, et al. Graphene oxide-decorated PLGA/ collagen hybrid fiber sheets for application to tissue engineering scaffolds. Biomater Res. 2014;18:18-24. doi:10.1186/2055-7124-18-18

203. Li Z, Wang H, Yang B, Sun Y, Huo R. Three-dimensional graphene foams loaded with bone marrow derived mesenchymal stem cells promote skin wound healing with reduced scarring. Mater Sci Eng C. 2015;57:181-188. doi:10.1016/j.msec.2015.07.062

204. Shin SR, Aghaei-Ghareh-Bolagh B, Dang TT, et al. Cell-laden microengineered and mechanically tunable hybrid hydrogels of gelatin and graphene oxide. Adv Mater. 2013;25(44):6385-6391. doi:10.1002/adma.201301082

205. Guo W, Wang S, Yu X, et al. Construction of a 3D rGO-collagen hybrid scaffold for enhancement of the neural differentiation of mesenchymal stem cells. Nanoscale. 2016;8(4):1897-1904. doi:10.1039/c5nr06602f

206. López-Dolado E, González-Mayorga A, Portolés MT, et al. Subacute tissue response to 3D graphene oxide scaffolds implanted in the injured rat spinal cord. Adv Healthc Mater. 2015;4(12):18611868. doi: $10.1002 /$ adhm. 201500333

207. Jiang Z, Song Q, Tang M, et al. Enhanced migration of neural stem cells by microglia grown on a three-dimensional graphene scaffold. ACS Appl Mater Interfaces. 2016;8(38):25069-25077. doi:10.1021/ acsami.6b06780

208. López-Dolado E, González-Mayorga A, Gutiérrez MC, Serrano MC. Immunomodulatory and angiogenic responses induced by graphene oxide scaffolds in chronic spinal hemisected rats. Biomaterials. 2016;99:72-81. doi:10.1016/j.biomaterials.2016. 05.012

209. Guo W, Zhang X, Yu X, et al. Self-powered electrical stimulation for enhancing neural differentiation of mesenchymal stem cells on graphene-poly (3, 4-ethylenedioxythiophene) hybrid microfibers. ACS Nano. 2016;10(5):5086-5095. doi:10.1021/acsnano.6b00200

210. Barrilleaux B, Phinney DG, Prockop DJ, O'connor KC. Review: ex vivo engineering of living tissues with adult stem cells. Tissue Eng. 2006;12(11):3007-3019. doi:10.1089/ten.2006.12.3007

211. Menaa F, Abdelghani A, Menaa B. Graphene nanomaterials as biocompatible and conductive scaffolds for stem cells: impact for tissue engineering and regenerative medicine. J Tissue Eng Regen Med. 2015;9(12):1321-1338. doi:10.1002/term.1910 
212. Bressan E, Ferroni L, Gardin C, et al. Graphene based scaffolds effects on stem cells commitment. J Transl Med. 2014;12(1):296. doi:10.1186/ s12967-014-0296-9

213. Gardin C, Piattelli A, Zavan B. Graphene in regenerative medicine: focus on stem cells and neuronal differentiation. Trends Biotechnol. 2016;34(6):435-437. doi:10.1016/j.tibtech.2016.01.006

214. Sayyar S, Bjorninen M, Haimi S, et al. UV Cross-linkable graphene/poly (trimethylene carbonate) composites for 3D printing of electrically conductive scaffolds. ACS Appl Mater Interfaces. 2016;8(46):31916-31925. doi:10.1021/acsami.6b09962

215. Akhavan O, Ghaderi E, Shirazian SA, Rahighi R. Rolled graphene oxide foams as three-dimensional scaffolds for growth of neural fibers using electrical stimulation of stem cells. Carbon. 2016;97:71-77. doi:10.1016/j.carbon.2015.06.079

216. Hassanein TI, Schade RR, Hepburn IS. Acute-on-chronic liver failure: extracorporeal liver assist devices. Curr Opin Crit Care. 2011;17(2):195-203. doi:10.1097/MCC.0b013e328344b3aa

217. Bhatia SN, Underhill GH, Zaret KS, Fox IJ. Cell and tissue engineering for liver disease. Sci Transl Med. 2014;6(245):245sr242245sr242. doi:10.1126/scitranslmed.3005975

218. Taub R. Liver regeneration: from myth to mechanism. Nat Rev Mol Cell Biol. 2004;5(10):836. doi:10.1038/nrm1489

219. Michalopoulos GK, DeFrances MC. Liver regeneration. Science. 1997;276(5309):60-66. doi:10.1126/science.276.5309.60

220. Lee SY, Kim HJ, Choi D. Cell sources, liver support systems and liver tissue engineering: alternatives to liver transplantation. Int $J$ Stem Cells. 2015;8(1):36. doi:10.15283/ijsc.2015.8.1.36

221. Palakkan AA, Hay DC, Kumary T, Ross JA. Liver tissue engineering and cell sources: issues and challenges. Liver Int. 2013;33 (5):666-676. doi:10.1111/liv.12134

222. Hammond JS, Beckingham IJ, Shakesheff KM. Scaffolds for liver tissue engineering. Expert Rev Med Devices. 2006;3(1):21-27. doi:10.1586/ 17434440.3.1.21

223. Chan C, Berthiaume F, Nath BD, Tilles AW, Toner M, Yarmush ML. Hepatic tissue engineering for adjunct and temporary liver support: critical technologies. Liver Transpl. 2004;10(11):13311342. doi:10.1002/1t.20229

224. Kaihara S, Borenstein J, Koka R, et al. Silicon micromachining to tissue engineer branched vascular channels for liver fabrication. Tissue Eng. 2000;6(2):105-117. doi:10.1089/107632700320739

225. Bhandari RN, Riccalton LA, Lewis AL, et al. Liver tissue engineering: a role for co-culture systems in modifying hepatocyte function and viability. Tissue Eng. 2001;7(3):345-357. doi:10.1089/10763270152044206

226. Dvir-Ginzberg M, Gamlieli-Bonshtein I, Agbaria R, Cohen S. Liver tissue engineering within alginate scaffolds: effects of cell-seeding density on hepatocyte viability, morphology, and function. Tissue Eng. 2003;9(4):757-766. doi:10.1089/107632703768247430

227. Shirakigawa N, Ijima H, Takei T. Decellularized liver as a practical scaffold with a vascular network template for liver tissue engineering. $J$ Biosci Bioeng. 2012;114(5):546-551. doi:10.1016/j.jbiosc.2012.05.022

228. Mayer J, Karamuk E, Akaike T, Wintermantel E. Matrices for tissue engineering-scaffold structure for a bioartificial liver support system. J Control Release. 2000;64(1-3):81-90.

229. Ohashi K, Yokoyama T, Yamato M, et al. Engineering functional two-and three-dimensional liver systems in vivo using hepatic tissue sheets. Nat Med. 2007;13(7):880. doi:10.1038/nm1576

230. Cho C, Seo S, Park I, et al. Galactose-carrying polymers as extracellular matrices for liver tissue engineering. Biomaterials. 2006;27 (4):576-585. doi:10.1016/j.biomaterials.2005.06.008

231. Lin P, Chan WC, Badylak SF, Bhatia SN. Assessing porcine liverderived biomatrix for hepatic tissue engineering. Tissue Eng. 2004;10(7-8):1046-1053. doi:10.1089/ten.2004.10.1046
232. Jiankang H, Dichen L, Yaxiong L, et al. Preparation of chitosangelatin hybrid scaffolds with well-organized microstructures for hepatic tissue engineering. Acta Biomater. 2009;5(1):453-461. doi:10.1016/j.actbio.2008.07.002

233. Wang X, Yan Y, Pan Y, et al. Generation of three-dimensional hepatocyte/gelatin structures with rapid prototyping system. Tissue Eng. 2006;12(1):83-90. doi:10.1089/ten.2006.12.83

234. Risbud MV, Karamuk E, Schlosser V, Mayer J. Hydrogel-coated textile scaffolds as candidate in liver tissue engineering: II. Evaluation of spheroid formation and viability of hepatocytes. $J$ Biomater Sci Polym Ed. 2003;14(7):719-731.

235. Zhu XH, Gan SK, Wang $\mathrm{CH}$, Tong YW. Proteins combination on PHBV microsphere scaffold to regulate Hep3B cells activity and functionality: a model of liver tissue engineering system. J Biomed Mater Res A. 2007;83(3):606-616.

236. Yang Z, Xu LS, Yin F, et al. In vitro and in vivo characterization of silk fibroin/gelatin composite scaffolds for liver tissue engineering. J Dig Dis. 2012;13(3):168-178.

237. Fiegel HC, Kaufmann PM, Bruns H, et al. Hepatic tissue engineering: from transplantation to customized cell-based liver directed therapies from the laboratory. J Cell Mol Med. 2008;12(1):56-66.

238. Kulig KM, Vacanti JP. Hepatic tissue engineering. Transpl Immunol. 2004;12(3-4):303-310.

239. Jiang J, Kojima N, Guo L, et al. Efficacy of engineered liver tissue based on poly-L-lactic acid scaffolds and fetal mouse liver cells cultured with oncostatin M, nicotinamide, and dimethyl sulfoxide. Tissue Eng. 2004;10(9-10):1577-1586.

240. Powers MJ, Domansky K, Kaazempur-Mofrad MR, et al. A microfabricated array bioreactor for perfused 3D liver culture. Biotechnol Bioeng. 2002;78(3):257-269.

241. Sabetkish S, Kajbafzadeh AM, Sabetkish N, et al. Whole-organ tissue engineering: decellularization and recellularization of threedimensional matrix liver scaffolds. J Biomed Mater Res Part A. 2015;103(4):1498-1508.

242. Kim SS, Utsunomiya H, Koski JA, et al. Survival and function of hepatocytes on a novel three-dimensional synthetic biodegradable polymer scaffold with an intrinsic network of channels. Ann Surg. 1998;228(1):8.

243. Ohashi K, Waugh JM, Dake MD, et al. Liver tissue engineering at extrahepatic sites in mice as a potential new therapy for genetic liver diseases. Hepatology. 2005;41(1):132-140.

244. Dash A, Inman W, Hoffmaster K, et al. Liver tissue engineering in the evaluation of drug safety. Expert Opin Drug Metab Toxicol. 2009;5(10):1159-1174.

245. Mazza G, Al-Akkad W, Rombouts K, Pinzani M. Liver tissue engineering: from implantable tissue to whole organ engineering. Hepatol Commun. 2018;2(2):131-141.

246. Nicolas CT, Hickey RD, Chen HS, et al. Concise review: liver regenerative medicine: from hepatocyte transplantation to bioartificial livers and bioengineered grafts. Stem Cells. 2017;35(1):42-50.

247. Fiegel HC, Kneser U, Kluth D, Metzger R, Till H, Rolle U. Development of hepatic tissue engineering. Pediatr Surg Int. 2009;25(8):667-673.

248. Tong XF, Zhao FQ, Ren YZ, Zhang Y, Cui YL, Wang QS. Injectable hydrogels based on glycyrrhizin, alginate, and calcium for three-dimensional cell culture in liver tissue engineering. $J$ Biomed Mater Res B Appl Biomater. 2018;106:3292-3302.

249. Lewis PL, Green RM, Shah RN. 3D-printed gelatin scaffolds of differing pore geometry modulate hepatocyte function and gene expression. Acta Biomater. 2018;69:63-70.

250. Lee JW, Choi Y-J, Yong W-J, et al. Development of a 3D cell printed construct considering angiogenesis for liver tissue engineering. Biofabrication. 2016;8(1):015007. 
251. Song W, Lu Y-C, Frankel AS, An D, Schwartz RE, Ma M. Engraftment of human induced pluripotent stem cell-derived hepatocytes in immunocompetent mice via $3 \mathrm{D}$ co-aggregation and encapsulation. Sci Rep. 2015;5:16884.

252. Ozbolat IT, Hospodiuk M. Current advances and future perspectives in extrusion-based bioprinting. Biomaterials. 2016;76:321-343.

253. Jeon H, Kang K, Park SA, et al. Generation of multilayered 3D structures of HepG2 cells using a bio-printing technique. Gut Liver. 2017;11(1):121.

254. Kang K, Kim Y, Jeon H, et al. Three-dimensional bioprinting of hepatic structures with directly converted hepatocyte-like cells. Tissue Eng Part A. 2018;24(7-8):576-583.

255. Lee JS, Shin J, Park H-M, et al. Liver extracellular matrix providing dual functions of two-dimensional substrate coating and threedimensional injectable hydrogel platform for liver tissue engineering. Biomacromolecules. 2013;15(1):206-218.

256. Uygun BE, Yarmush ML, Uygun K. Application of whole-organ tissue engineering in hepatology. Nat Rev Gastroenterol Hepatol. 2012;9(12):738.

257. Mazza G, Al-Akkad W, Rombouts K. Engineering in vitro models of hepatofibrogenesis. Adv Drug Deliv Rev. 2017;121:147-157.

258. Bianco A. Graphene: safe or toxic? The two faces of the medal. Angew Chem Int Ed. 2013;52(19):4986-4997.

259. Li Y, Wang Y, Tu L, et al. Sub-acute toxicity study of graphene oxide in the Sprague-Dawley rat. Int J Environ Res Public Health. 2016;13(11):1149.

260. Horvath L, Magrez A, Burghard M, Kern K, Forró L, Schwaller B. Evaluation of the toxicity of graphene derivatives on cells of the lung luminal surface. Carbon. 2013;64:45-60.

261. Liu J-H, Yang S-T, Wang H, Chang Y, Cao A, Liu Y. Effect of size and dose on the biodistribution of graphene oxide in mice. Nanomedicine. 2012;7(12):1801-1812.

262. Zhou H, Cheng C, Qin H, et al. Self-assembled 3D biocompatible and bioactive layer at the macro-interface via graphene-based supermolecules. Polym Chem. 2014;5(11):3563-3575.
263. Song SH, Jang M-H, Jeong J-M, et al. Primary hepatocyte imaging by multiphoton luminescent graphene quantum dots. Chem Commun. 2015;51(38):8041-8043.

264. Loeblein M, Perry G, Tsang SH, et al. Three-dimensional graphene: a biocompatible and biodegradable scaffold with enhanced oxygenation. Adv Healthcare Mater. 2016:1177-1191.

265. Mohamed WNAEM, El Din TAS, Tohamy AAE-M, El-yamany NA, Amin AS. Evaluation of genotoxic and hepatotoxic effects of graphene oxide nanosheets in male albino mice. Egypt J Exp Biol (Zoo). 2017;13(1):43-53.

266. Starokozhko V, Hemmingsen M, Larsen L, et al. Differentiation of human-induced pluripotent stem cell under flow conditions to mature hepatocytes for liver tissue engineering. J Tissue Eng Regen Med. 2018;12(5):1273-1284.

267. Grant R, Hay D, Callanan A. From scaffold to structure: the synthetic production of cell derived extracellular matrix for liver tissue engineering. Biomed Phys Eng Express. 2018;4:1-13.

268. Fu J, Wang D-A. In situ organ-specific vascularization in tissue engineering. Trends Biotechnol. 2018;36:834-849.

269. Jastrzębska AM, Kurtycz P, Olszyna AR. Recent advances in graphene family materials toxicity investigations. J Nanopart Res. 2012;14(12):1320.

270. Liu J, Tang J, Gooding JJ. Strategies for chemical modification of graphene and applications of chemically modified graphene. $J$ Mater Chem. 2012;22(25):12435-12452.

271. Caffo M, Merlo L, Marino D, Caruso G. Biomedical applications of graphene. In: Aliofkhazraei M, Ali N, Milne WI, Ozkan CS, Stanislaw Mitura S, Gervasoni JL, editors. Graphene Science Handbook: Applications and Industrialization. Boca Raton: CRC Press, Taylor \& Francis; 2016:41-56.

272. Holmes B, Bulusu K, Plesniak M, Zhang LG. A synergistic approach to the design, fabrication and evaluation of $3 \mathrm{D}$ printed micro and nano featured scaffolds for vascularized bone tissue repair. Nanotechnology. 2016;27(6):064001.
International Journal of Nanomedicine

\section{Publish your work in this journal}

The International Journal of Nanomedicine is an international, peerreviewed journal focusing on the application of nanotechnology in diagnostics, therapeutics, and drug delivery systems throughout the biomedical field. This journal is indexed on PubMed Central, MedLine, CAS, SciSearch ${ }^{\circledR}$, Current Contents ${ }^{\circledR} /$ Clinical Medicine,
Journal Citation Reports/Science Edition, EMBase, Scopus and the Elsevier Bibliographic databases. The manuscript management system is completely online and includes a very quick and fair peer-review system, which is all easy to use. Visit http://www.dovepress.com/ testimonials.php to read real quotes from published authors. 